University of Nebraska - Lincoln

DigitalCommons@University of Nebraska - Lincoln

Publications, Agencies and Staff of the U.S.

Department of Commerce

U.S. Department of Commerce

2012

\title{
Mercury in the Gulf of Mexico: Sources to receptors
}

\author{
Reed Harris \\ Reed Harris Environmental Ltd., reed@reed-harris.com \\ Curtis Pollman \\ Aqua Lux Lucis, Inc., cpollman@aqualuxlucis.org \\ William Landing \\ Florida State University \\ David Evans \\ NOAA, David.W.Evans@noaa.gov \\ Donald Axelrad \\ Florida Department of Environmental Protection, Don.Axelrad@dep.state.fl.us \\ See next page for additional authors
}

Follow this and additional works at: https://digitalcommons.unl.edu/usdeptcommercepub

Part of the Environmental Sciences Commons

Harris, Reed; Pollman, Curtis; Landing, William; Evans, David; Axelrad, Donald; Hutchinson, David; Morey, Steven L.; Rumbold, Darren; Dukhovskoy, Dmitry; Adams, Douglas H.; Vijayaraghavan, Krish; Holmes, Christopher; Atkinson, R. Dwight; Myers, Tom; and Sunderland, Elsie, "Mercury in the Gulf of Mexico: Sources to receptors" (2012). Publications, Agencies and Staff of the U.S. Department of Commerce. 382. https://digitalcommons.unl.edu/usdeptcommercepub/382

This Article is brought to you for free and open access by the U.S. Department of Commerce at DigitalCommons@University of Nebraska - Lincoln. It has been accepted for inclusion in Publications, Agencies and Staff of the U.S. Department of Commerce by an authorized administrator of DigitalCommons@University of Nebraska - Lincoln. 


\section{Authors}

Reed Harris, Curtis Pollman, William Landing, David Evans, Donald Axelrad, David Hutchinson, Steven L. Morey, Darren Rumbold, Dmitry Dukhovskoy, Douglas H. Adams, Krish Vijayaraghavan, Christopher Holmes, R. Dwight Atkinson, Tom Myers, and Elsie Sunderland 


\title{
Mercury in the Gulf of Mexico: Sources to receptors
}

\author{
Reed Harris ${ }^{\mathrm{a}, *}$, Curtis Pollman ${ }^{\mathrm{b}}$, William Landing ${ }^{\mathrm{c}}$, David Evans ${ }^{\mathrm{d}}$, Donald Axelrad ${ }^{\mathrm{e}}$, David Hutchinson ${ }^{\mathrm{a}}$, \\ Steven L. Morey ${ }^{\mathrm{f}}$, Darren Rumbold ${ }^{\mathrm{g}}$, Dmitry Dukhovskoy ${ }^{\mathrm{f}}$, Douglas H. Adams ${ }^{\mathrm{h}}$, Krish Vijayaraghavan ${ }^{\mathrm{i}}$, \\ Christopher Holmes ${ }^{\mathrm{j}}$, R. Dwight Atkinson ${ }^{\mathrm{k}}$, Tom Myers ${ }^{1}$, Elsie Sunderland ${ }^{\mathrm{m}}$
}

${ }^{a}$ Reed Harris Environmental Ltd, 180 Forestwood Drive, Oakville, Ontario, Canada, L6J4E6

${ }^{\mathrm{b}}$ Aqua Lux Lucis, Inc., 8411 NW 55th PL, Gainesville, FL 32653, USA

c Florida State University, Department of Earth, Ocean, and Atmospheric Science, 117N. Woodward Ave., Tallahassee, FL 32306-4320, USA

' NOAA, 101 Pivers Island Road, Beaufort, NC 28516, USA

e Florida Department of Environmental Protection, 2600 Blair Stone Road, MS-6511, Tallahassee, FL 32399-2400, USA

${ }^{\mathrm{f}}$ Florida State University, Center for Ocean-Atmospheric Prediction Studies, Tallahassee, FL 32306-2840, USA

${ }^{g}$ Florida Gulf Coast University,10501 FGCU Blvd. South, Fort Myers, FL 33965, USA

${ }^{\mathrm{h}}$ Florida Fish and Wildife Conservation Commission, Fish \& Wildlife Research Institute, 1220 Prospect Ave., \#285, Melbourne, FL 32901, USA

${ }^{i}$ ENVIRON International Corporation, 773 San Marin Drive, Suite 2115, Novato, CA 94998, USA

${ }^{\mathrm{j}}$ University of California, Irvine, Department of Earth System Sciences, 2101 Croul Hall, Irvine, CA 92697-3100, USA

${ }^{\mathrm{k}}$ US EPA Office of Water (4503-T), 1200 Pennsylvania Ave. NW, Washington, DC 20004, USA

${ }^{1}$ ICF International, 101 Lucas Valley Road, Suite 260, San Rafael, CA 94903, USA

${ }^{\mathrm{m}}$ Harvard University, Department of Environmental Health, Harvard School of Public Health, 401 Park Drive, Boston, MA 02115, USA

\section{A R T I C L E I N F O}

Keywords:

Mercury

Methylmercury

Bioaccumulation

Risk

Gulf of Mexico

\begin{abstract}
A B S T R A C T
Gulf of Mexico (Gulf) fisheries account for $41 \%$ of the U.S. marine recreational fish catch and $16 \%$ of the nation's marine commercial fish landings. Mercury $(\mathrm{Hg})$ concentrations are elevated in some fish species in the Gulf, including king mackerel, sharks, and tilefish. All five Gulf states have fish consumption advisories based on Hg. Per-capita fish consumption in the Gulf region is elevated compared to the U.S. national average, and recreational fishers in the region have a potential for greater $\mathrm{MeHg}$ exposure due to higher levels of fish consumption. Atmospheric wet $\mathrm{Hg}$ deposition is estimated to be higher in the Gulf region compared to most other areas in the U.S., but the largest source of $\mathrm{Hg}$ to the Gulf as a whole is the Atlantic Ocean (>90\%) via large flows associated with the Loop Current. Redistribution of atmospheric, Atlantic and terrestrial $\mathrm{Hg}$ inputs to the Gulf occurs via large scale water circulation patterns, and further work is needed to refine estimates of the relative importance of these $\mathrm{Hg}$ sources in terms of contributing to fish $\mathrm{Hg}$ levels in different regions of the Gulf. Measurements are needed to better quantify external loads, in-situ concentrations, and fluxes of total $\mathrm{Hg}$ and methylmercury in the water column, sediments, and food web.
\end{abstract}

(c) 2012 Elsevier Inc. All rights reserved.

\section{Introduction}

Gulf of Mexico (Gulf) fisheries account for $41 \%$ of the U.S. marine recreational fish catch and $16 \%$ of the nation's marine commercial fish landings (NOAA, 2011). These fisheries are economically important in the region (NMFS, 2006). While fish consumption has well established health benefits (Mahaffey

\footnotetext{
This research has not involved human subjects or experimental animals * Corresponding author.

E-mail addresses: reed@reed-harris.com (R. Harris), cpollman@aqualuxlucis.org (C. Pollman), David.W.Evans@noaa.gov (D. Evans), Don.Axelrad@dep.state.fl.us (D. Axelrad), morey@coaps.fsu.edu (S.L. Morey), drumbold@fgcu.edu (D. Rumbold), Doug.Adams@MyFWC.com (D.H. Adams), krish@environcorp.com (K. Vijayaraghavan), elsie_sunderland@harvard.edu (E. Sunderland).
}

et al., 2011) there is a global concern regarding exposure to methylmercury ( $\mathrm{MeHg})$, a toxic form of mercury $(\mathrm{Hg})$ present in fish. Excess exposure to $\mathrm{MeHg}$ can cause neurotoxicological and cardiovascular effects in humans (Mergler et al., 2007). The benefits and risks associated with eating fish have led to confusing messages for the public, compounded by widely varying fish MeHg concentrations (2-3 orders of magnitude) among species, locations and sizes. Should people eat fish, and if so, which fish (see Oken et al., 2012)?

While MeHg occurs naturally and has undoubtedly always been present in fish, industrialization has resulted in higher levels of $\mathrm{Hg}$ mobilization and emissions in the biosphere, very likely producing higher fish $\mathrm{MeHg}$ concentrations on a global scale (Munthe et al., 2007). As MeHg is a toxin of no known use to organisms, lower MeHg levels in the environment would be beneficial. Efforts are ongoing to reduce $\mathrm{Hg}$ releases to the 
environment nationally and internationally (e.g. US EPA, 2011a; UNEP, 2011).

Elevated $\mathrm{Hg}$ concentrations have been reported in some higher trophic level fish species in the Atlantic and Pacific Oceans (Sunderland, 2007), and in the Gulf, where king mackerel (Scomberomorus cavalla) $\mathrm{Hg}$ concentrations have been reported up to $4.0 \mu \mathrm{g} \mathrm{g}^{-1}$ wet muscle (Adams and McMichael, 2007; Lowery and Garrett, 2005), and blue marlin (Makaira nigricans) concentrations above $10 \mu \mathrm{g} \mathrm{g}^{-1}$ were reported by Cai et al. (2007). The US EPA national Water Quality Criterion for the Protection of Human Health is, by comparison, $0.3 \mu \mathrm{g} \mathrm{Hg} \mathrm{g}^{-1}$ wet muscle (US EPA, 2001). All five Gulf States (Texas, Louisiana, Mississippi, Alabama and Florida) have "do not eat" advisories on king mackerel for women of childbearing age and children (US EPA, 2003). Florida lists over 60 Gulf species in its fish consumption advisory regarding $\mathrm{Hg}(\mathrm{FDOH}, 2012)$. While fish caught in the Gulf are marketed nationally, the $\mathrm{Hg}$ issue is of particular relevance to residents in the Gulf region, who eat more fish than the U.S. average (Mahaffey et al., 2009; US EPA, 2002; Degner et al., 1994).

Despite the importance of Gulf fisheries, our understanding of the main sources of $\mathrm{Hg}$ to the Gulf and factors controlling $\mathrm{MeHg}$ levels in the Gulf food web is inadequate. An improved characterization and understanding of $\mathrm{Hg}$ in the Gulf is needed to provide decision makers with a sound scientific basis to assess current risks and the benefits of emissions control strategies. Here we report on the current state of knowledge of $\mathrm{Hg}$ sources, cycling, bioaccumulation and human exposure in the Gulf of Mexico. A companion paper (Harris et al., this issue) describes the application of a screening level $\mathrm{Hg}$ mass balance model to examine $\mathrm{Hg}$ loading, cycling and bioaccumulation in the Gulf.

\section{Description of Gulf of Mexico}

The Gulf of Mexico has an area of approximately 1.6 million $\mathrm{km}^{2}$ and a maximum depth of $\sim 4 \mathrm{~km}$ (Fig. 1, Table 1). A large continental shelf represents about $30 \%$ of the total area. The Gulf is bordered by three countries: the United States (5 states), Mexico, and Cuba. There are 47 major estuaries (UNEP, 2009) and salinity shows significant seasonal variability in the northern Gulf due to seasonal shifts in circulation over the continental shelves and a large seasonal signal in freshwater discharge, primarily from the Mississippi and Atchafalaya Rivers (Morey et al., 2005). The Mississippi River drainage basin (Fig. 1) has an area of 3.2 million $\mathrm{km}^{2}$, representing nearly two-thirds of the total drainage basin for the Gulf, and includes $41 \%$ of the contiguous continental United States area (US EPA, 2010). The largest source of water to the Gulf, however, is the Atlantic Ocean, via the Loop Current, whose flow is approximately three orders of magnitude greater than the water load from the Mississippi drainage basin (Morey et al., 2005). The Loop Current enters the Gulf through the Yucatan Channel and exits through the Straits of Florida. This current and other large-scale water circulation patterns in the Gulf redistribute $\mathrm{Hg}$ loads from the atmosphere, Atlantic Ocean, and terrestrial inputs.

Mean annual temperatures at the sea surface are in the range of 26-27 ${ }^{\circ} \mathrm{C}$ (UNEP, 2009). Dissolved organic carbon is on the order of $1 \mathrm{mg} \mathrm{L}^{-1}$ in open waters in the Gulf (Baskaran et al., 1996; Guo et al., 1995; Del Castillo et al., 2000) and the $\mathrm{pH}$ is $\sim 8$ (Solomon et al., 2007). The Gulf is a moderately high productivity system (150-300 $\mathrm{g} \mathrm{C} \mathrm{m}^{-2} \mathrm{yr}^{-1}$ ) although conditions range from eutrophic in some coastal waters to oligotrophic in deep water areas (UNEP, 2009). A large hypoxic area $\left(\sim 15,000-20,000 \mathrm{~km}^{2}\right)$ forms in summer in bottom waters over a portion of the northern shelf.

\section{Inorganic $\mathrm{Hg}$ in the Gulf of Mexico}

\subsection{Hg sources to the Gulf}

Fish $\mathrm{Hg}$ concentrations are affected by the rate of $\mathrm{Hg}$ loading to a waterbody (Munthe et al., 2007 review). This is clearly evident in studies of point source contamination in freshwater systems (Parks and Hamilton, 1987), coastal and estuarine systems (Herut

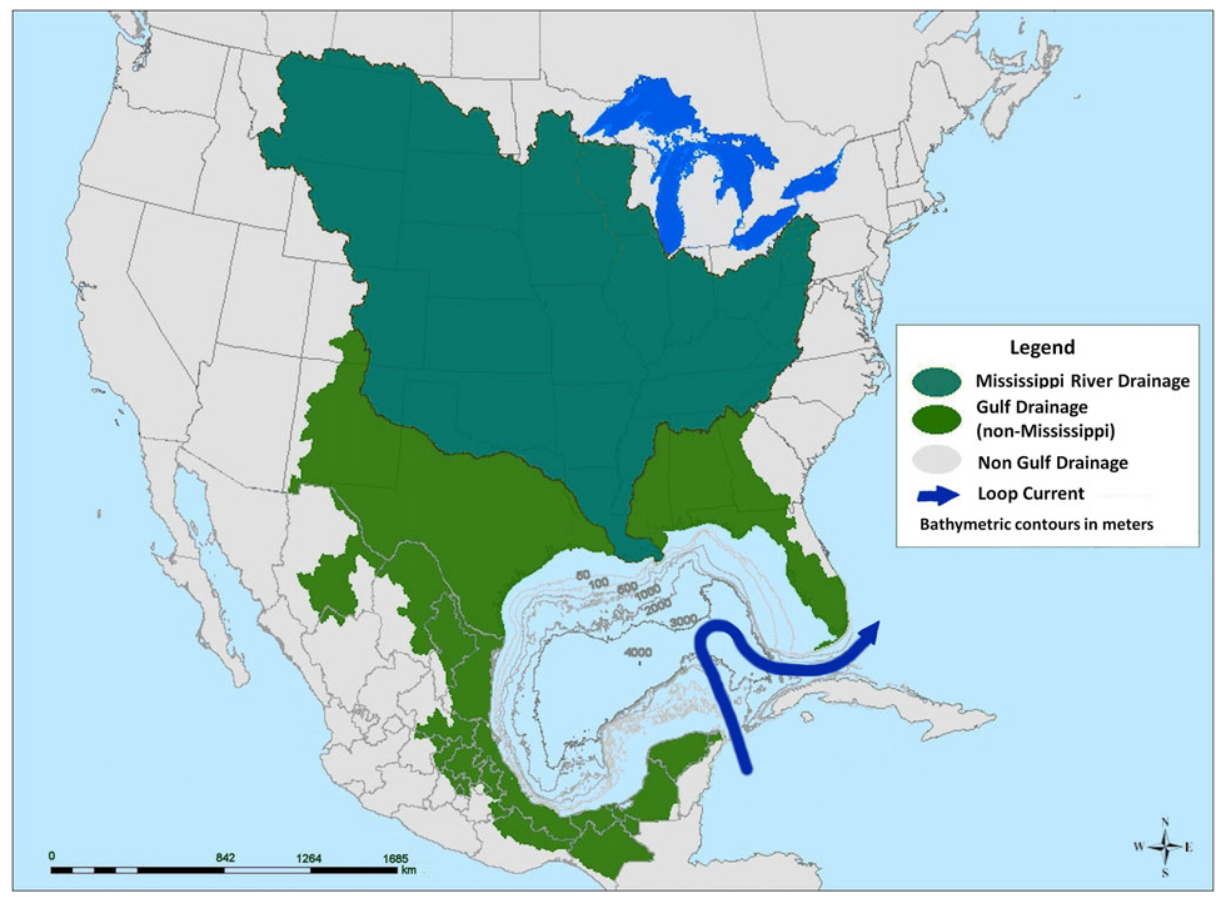

Fig. 1. Map of Gulf of Mexico and drainage basin. Drainage from Cuba not available.

Source: Adapted from map created by J.C. Allen, U.S. EPA Gulf of Mexico Program Office. 
Table 1

General characteristics of the Gulf of Mexico.

\begin{tabular}{|c|c|c|}
\hline Characteristic & Value & Data source \\
\hline Surface area $\left(\mathrm{km}^{2}\right)$ & $\sim 1.6 \times 10^{6}$ & NCOM model (S. Morey, Florida State University), UNEP (2009) \\
\hline Drainage basin area $\left(\mathrm{km}^{2}\right)$ & $\sim 4.8 \times 10^{6}$ & US EPA (2011b) \\
\hline Volume $\left(\mathrm{km}^{3}\right)$ & $\sim 2.4 \times 10^{6}$ & NCOM model (S. Morey, Florida State University) \\
\hline Maximum depth (m) & $\sim 4000$ & NCOM outputs (S. Morey, Florida State University) \\
\hline Mean depth (m) & $\sim 1500$ & Derived from NCOM outputs \\
\hline $\mathrm{pH}^{\mathrm{a}}$ & 8.1 & Solomon et al. (2007) \\
\hline Dissolved organic carbon $\left(\mathrm{mg} \mathrm{L}^{-1}\right)^{\mathrm{a}}$ & $\sim 1$ & Baskaran et al. (1996), Guo et al. (1995), Del Castillo et al. (2000) \\
\hline Suspended solids $\left(\mathrm{mg} \mathrm{L}^{-1}\right)^{\mathrm{a}}$ & $\sim 2$ to $>100$ & Goni et al. (2006), Carranza-Edwards et al. (1993), Baskaran et al. (1996) \\
\hline Mean annual surface temperature $(C)^{a}$ & $26-27$ & $\operatorname{UNEP}(2009)$ \\
\hline Deep water temperature $(C)^{a}$ & 5 & Loubere et al. (1993) \\
\hline Biological productivity $\left(\mathrm{gC} \mathrm{m}^{-2} \mathrm{yr}^{-1}\right)$ & Moderate (150-300) & UNEP (2009) \\
\hline Sediment organic content ${ }^{\mathrm{a}}$ & Coastal: $\sim 1-2 \%$, Pelagic: $\sim 1-2 \%$ & Kennicut et al. (1995), Yeager et al. (2004) \\
\hline Total $\mathrm{Hg}$ concentration in water column $\left(\mathrm{ng} \mathrm{L}^{-1}\right)$ & No data & $\mathrm{N} / \mathrm{A}$ \\
\hline Methyl $\mathrm{Hg}$ concentration in water column $\left(\mathrm{ng} \mathrm{L}^{-1}\right)$ & No data & $\mathrm{N} / \mathrm{A}$ \\
\hline Total $\mathrm{Hg}$ concentration in sediments ( $\mathrm{ng} \mathrm{g}^{-1}$ ) & $5-80$ & Liu et al. (2009), Kannan et al. (1998), Delaune et al. (2008) \\
\hline Methyl $\mathrm{Hg}$ concentrations in sediments $\left(\mathrm{ng} \mathrm{g}^{-1}\right)$ & $\sim 0.02$ to $0.3(<=1 \%$ of total $\mathrm{Hg})$ & Liu et al. (2009) \\
\hline
\end{tabular}

$\mathrm{NA}=$ Not applicable

a Coastal shelf and pelagic areas.

et al., 1996; Francesconi et al., 1997), and has been demonstrated for smaller changes in ecosystem $\mathrm{Hg}$ loading relevant to changes in atmospheric $\mathrm{Hg}$ deposition (Harris et al., 2007). It is therefore critical to quantify the current sources of $\mathrm{Hg}$ to the Gulf, which can be broadly grouped as atmospheric, terrestrial and Atlantic inputs. External $\mathrm{Hg}$ loads to the Gulf were estimated as part of a mass balance modeling study by Harris et al. (this issue) and are summarized here. Hg inputs to the Gulf were assumed to be small from hydrothermal vents (Mason et al., this issue; Lamborg et al., 2006) and oil and gas exploration rigs (Neff, 2002).

Atlantic $\mathrm{Hg}$ inputs are dominated by the Loop Current which enters through the Yucatan Channel with a flow of approximately $27 \mathrm{~Sv}\left(1 \mathrm{~Sv}=10^{6} \mathrm{~m}^{3} \mathrm{~s}^{-1}\right)$. Inflowing Atlantic $\mathrm{Hg}$ concentrations were estimated from the literature, as no direct measurements of $\mathrm{Hg}$ concentrations in the Loop Current were available. Sunderland and Mason (2007) reported total $\mathrm{Hg}$ ( $\mathrm{THg}$ ) concentrations in Atlantic waters (north, south, equatorial) that averaged $0.43 \mathrm{ng} \mathrm{L}^{-1}(n=6)$. Based on that estimate, the Atlantic input of $\mathrm{THg}$ to the Gulf was approximately $240 \mu \mathrm{g} \mathrm{m}^{-2} \mathrm{yr}^{-1}$ (Harris et al., this issue).

The riverine $\mathrm{Hg}$ load to Gulf coastal waters estimated by Harris et al. (this issue) was $\sim 7 \mu \mathrm{g} \mathrm{m}^{-2} \mathrm{yr}^{-1}$, of which more than $90 \%$ was associated with the Mississippi and Atchafalaya Rivers. Rice et al. (2008) estimated loads of 6.25 and $3.25 \mathrm{t} \mathrm{Hg} \mathrm{yr}^{-1}$ respectively for these rivers, primarily associated with particulates. Dissolved $\mathrm{Hg}$ loads from these two rivers were estimated by Rice et al. (2008) using the US EPA's SERAFM model, rather than direct observations (Knightes, 2008). Site data for riverine $\mathrm{Hg}$ concentrations and loads to most other regions of the Gulf were not available. Using median stream concentrations of $1.90 \mathrm{ng} \mathrm{L}^{-1}$ ( $\mathrm{THg}$ ) and $0.11 \mathrm{ng} \mathrm{L}^{-1}$ (MeHg) from a USGS national survey by Scudder et al. (2009) (basins without mining activities), and allowing for estuarine $\mathrm{Hg}$ trapping of a portion of riverine $\mathrm{Hg}$ prior to entering coastal waters in the Gulf $(\sim 50 \%$, see Harris et al., in this issue)), $\mathrm{Hg}$ concentrations assigned for other riverine inputs to the Gulf ranged from $1-3 \mathrm{ng} \mathrm{L}^{-1}$ for inorganic $\mathrm{Hg}$ and 0.03 to $0.10 \mathrm{ng} \mathrm{L}^{-1}$ for $\mathrm{MeHg}$. River $\mathrm{Hg}$ concentrations can vary widely, e.g. Scudder et al. (2009) reported a range of 0.27 to $75 \mathrm{ng} \mathrm{L}^{-1}$ in streams without mining activities. This highlights the fact that riverine $\mathrm{Hg}$ loads to the Gulf are under-constrained due to a lack of data on riverine $\mathrm{Hg}$ concentrations and uncertainty regarding the effects of estuaries on $\mathrm{Hg}$ delivery to marine waters.

Atmospheric $\mathrm{Hg}$ inputs to the Gulf were estimated with a combination of field observations and modeling. Wet deposition observations are available at several land sites in the Gulf region (Table 2), but atmospheric models are needed to estimate wet $\mathrm{Hg}$ deposition over Gulf waters, as well as dry deposition throughout the Gulf domain (no systematic monitoring of dry $\mathrm{Hg}$ deposition exists). While the mass balance modeling carried out by Harris et al. (this issue) used results from the AMSTERDAM model (the Advanced Modeling System for Transport, Emissions, Reactions and Deposition of Atmospheric Matter) (Vijayaraghavan et al., 2007,2008), here we also include outputs from two additional models: GEOS-Chem (Holmes et al., 2010) and REMSAD (the Regional Modeling System for Aerosols and Deposition) (Atkinson et al., 2008). Details regarding the mechanisms and rates used in these models for inter-conversion between inorganic atmospheric $\mathrm{Hg}$ forms and subsequent deposition can be found in those references. Modeled estimates ranged from $7-16 \mu \mathrm{g} \mathrm{m}^{-2} \mathrm{yr}^{-1}$ among the models for wet deposition and 14-28 $\mu \mathrm{g} \mathrm{m}^{-2} \mathrm{yr}^{-1}$ for combined wet and dry $\mathrm{THg}$ deposition (Table 2). Dry deposition of $\mathrm{Hg}$ ranged from $\sim 25-50 \%$ of the total estimated deposition across models but presented less seasonal variability than wet deposition. Additional information on the development of atmospheric $\mathrm{Hg}$ deposition estimates is provided in Appendix A.

\subsection{Relative importance of inorganic $\mathrm{Hg}$ sources}

When the Gulf is viewed as a whole, the Loop Current dominates Hg loading (Fig. 2), accounting for $85-90 \%$ of the total supply. The whole-Gulf perspective is misleading however, because surface waters and $\mathrm{Hg}$ are not fully mixed around the Gulf of Mexico; some areas are not as influenced by the Loop Current as others. In a screening model analysis that divided the Gulf into 19 regions, the relative importance of external $\mathrm{Hg}$ sources varied widely among regions (Harris et al., this issue). Each of the three external Hg loads was the largest predicted source to at least one of the model regions. In the central Gulf the Loop Current was the largest predicted source of inorganic $\mathrm{Hg}$. Inputs from the Mississippi and Atchafalaya River were the largest source of $\mathrm{Hg}$ in coastal waters in the vicinity of these rivers. Atmospheric deposition was predicted to be the largest source of $\mathrm{Hg}$ along the coast of Florida.

Although we examined the $\mathrm{Hg}$ contributions from direct deposition, the Atlantic Ocean and rivers, all of these $\mathrm{Hg}$ sources to the Gulf typically link back primarily to atmospheric $\mathrm{Hg}$ deposition (assuming hydrothermal vents are not an important source of $\mathrm{Hg}$ to the Atlantic). Exceptions include terrestrial areas 
Table 2

Comparison of modeled mercury deposition to the Gulf of Mexico with measured wet deposition. All fluxes in $\mu \mathrm{g} \mathrm{m}^{-2}$ for appropriate time period.

\begin{tabular}{|c|c|c|c|c|c|c|c|c|c|c|c|c|c|}
\hline \multirow[t]{2}{*}{ Month } & \multicolumn{3}{|c|}{ REMSAD } & \multicolumn{4}{|c|}{ GEOS-Chem } & \multicolumn{3}{|c|}{ AMSTERDAM } & \multirow{2}{*}{$\begin{array}{l}\text { PAMS (3 sites) } \\
(2005-2010) \\
\text { Wet }\end{array}$} & \multirow{2}{*}{$\begin{array}{l}\text { MDN AL24 } \\
\text { (2005-2009) } \\
\text { Wet }\end{array}$} & \multirow{2}{*}{$\begin{array}{l}\text { MDN FL05 } \\
\text { (2005-2010) } \\
\text { Wet }\end{array}$} \\
\hline & Wet & Dry & Total & Wet & Dry (Hg(II)) & Dry $\left(\mathrm{Hg}^{\mathrm{o}}\right)$ & Total & Wet & Dry & Total & & & \\
\hline January & 0.74 & 0.45 & 1.19 & 0.57 & 0.52 & 0.27 & 1.35 & 0.83 & 0.75 & 1.57 & 1.40 & 1.10 & 0.95 \\
\hline February & 0.74 & 0.45 & 1.19 & 0.51 & 0.37 & 0.20 & 1.08 & 0.85 & 0.99 & 1.83 & 0.83 & 0.93 & 0.52 \\
\hline March & 1.00 & 0.57 & 1.57 & 0.59 & 0.52 & 0.25 & 1.36 & 0.81 & 0.96 & 1.77 & 0.68 & 1.77 & 1.15 \\
\hline April & 1.00 & 0.57 & 1.57 & 0.51 & 0.46 & 0.18 & 1.15 & 0.52 & 1.04 & 1.56 & 1.17 & 1.81 & 0.68 \\
\hline May & 1.00 & 0.57 & 1.57 & 0.66 & 0.29 & 0.15 & 1.10 & 0.66 & 1.52 & 2.18 & 1.33 & 1.74 & 1.12 \\
\hline June & 2.01 & 0.33 & 2.34 & 1.08 & 0.31 & 0.10 & 1.48 & 1.94 & 0.93 & 2.87 & 1.43 & 1.30 & 2.91 \\
\hline July & 2.01 & 0.33 & 2.34 & 0.83 & 0.31 & 0.09 & 1.22 & 1.71 & 0.82 & 2.54 & 1.75 & 3.50 & 3.96 \\
\hline August & 2.01 & 0.33 & 2.34 & 0.60 & 0.24 & 0.07 & 0.90 & 2.30 & 1.01 & 3.31 & 3.31 & 1.76 & 3.43 \\
\hline September & 1.34 & 0.52 & 1.86 & 0.60 & 0.30 & 0.12 & 1.01 & 2.63 & 0.83 & 3.46 & 1.18 & 1.65 & 1.69 \\
\hline October & 1.34 & 0.52 & 1.86 & 0.53 & 0.47 & 0.15 & 1.14 & 1.76 & 0.77 & 2.53 & 0.93 & 0.88 & 0.77 \\
\hline November & 1.34 & 0.52 & 1.86 & 0.30 & 0.51 & 0.16 & 0.96 & 0.90 & 1.03 & 1.93 & 0.66 & 0.69 & 0.71 \\
\hline December & 0.74 & 0.45 & 1.19 & 0.31 & 0.42 & 0.23 & 0.95 & 1.04 & 1.00 & 2.05 & 0.81 & 1.44 & 0.71 \\
\hline Annual & 15.26 & 5.61 & 20.87 & 7.08 & 4.70 & 1.93 & 13.71 & 15.96 & 11.65 & 27.62 & 15.48 & 18.56 & 18.60 \\
\hline
\end{tabular}

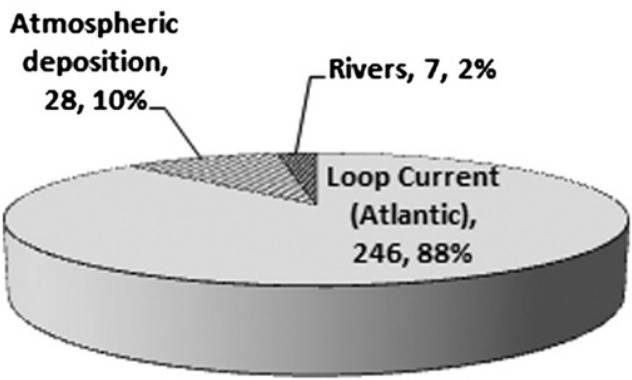

Fig. 2. Estimated Hg inputs to the Gulf of Mexico. From Harris et al. (this issue). First number for each input is in units of $\mu \mathrm{g} \mathrm{m}^{-2} \mathrm{yr}^{-1}$. Second number is percent of overall $\mathrm{Hg}$ load.

with enriched $\mathrm{Hg}$ deposits (Fitzgerald et al., 1997) or where there is point source industrial $\mathrm{Hg}$ contamination. Reducing atmospheric $\mathrm{Hg}$ deposition is therefore central to reducing overall $\mathrm{Hg}$ loading to the Gulf of Mexico. Furthermore, GEOS-Chem and REMSAD simulations estimate that most of the $\mathrm{Hg}$ in atmospheric deposition to the Gulf, on the order of 75 percent or more, originates from sources outside the United States. This does not mean that actions are not needed within the United States to reduce $\mathrm{Hg}$ emissions; rather it points to a need for a coordinated international effort to reduce $\mathrm{Hg}$ deposition to the Gulf of Mexico.

\section{MeHg sources in the Gulf of Mexico}

Loop Current inputs of MeHg are likely the largest external source of MeHg to the Gulf (Harris et al., this issue), while rates of in-situ methylation, and the primary sites of in-situ $\mathrm{MeHg}$ production, are not known. In-situ methylation is a topic of ongoing research in the oceans generally (see Mason et al., this issue). MeHg production in sediments has been widely documented for freshwater and marine aquatic systems (e.g. Hollweg et al., 2009; Sunderland et al., 2006; Hammerschmidt and Fitzgerald, 2004; Gilmour et al., 1992). MeHg production has also been recently been identified in the water column of the Pacific Ocean and Mediterranean Sea where MeHg concentrations peaked in both cases at intermediate depths, in the range of $0.08 \mathrm{ng} \mathrm{L}^{-1}$, while surface concentrations were lower, $\sim 0.01$ to $0.02 \mathrm{ng} \mathrm{L}^{-1}$ (Sunderland et al., 2009; Cossa et al., 2009, 2011;
Heimbürger et al., 2010). The large hypoxic zone in the northern Gulf shelf is also potentially a zone of enhanced water column production of $\mathrm{MeHg}$, as observed in other systems with low oxygen waters (Heimbürger et al., 2010; Sunderland et al., 2009; Cossa et al., 2009; Herrin et al., 1998). There are currently no water column $\mathrm{Hg}$ data available to resolve where $\mathrm{MeHg}$ is primarily produced in the Gulf.

It is essential to identify the primary sites of $\mathrm{Hg}$ methylation in the Gulf, especially those supplying MeHg to key fisheries with elevated MeHg levels, in order to evaluate the effectiveness of different $\mathrm{Hg}$ load reduction strategies. If water column methylation in intermediate depth waters is the primary source of in-situ MeHg production (Mason et al., this issue), inorganic Hg sources to these waters, e.g. Loop Current inputs, would be more important to control. Where sediment methylation in coastal zones is more important, terrestrial inputs would take on greater importance in terms of the source of $\mathrm{Hg}$ ultimately accumulating in fish.

The timing of the response of fish $\mathrm{Hg}$ concentrations to changes in atmospheric $\mathrm{Hg}$ deposition is also likely affected by the primary site of methylation. Methylation in zones strongly influenced by terrestrial $\mathrm{Hg}$ inputs, such as some coastal sediments, should change at a rate ultimately controlled by the slow decline of terrestrial $\mathrm{Hg}$ inputs. Terrestrial $\mathrm{Hg}$ export in streams lags changes in deposition, likely on a scale of decades or centuries (Krabbenhoft et al., 2006; Harris et al., 2007; Munthe et al., 2007; Munthe and Hultberg, 2004). Water column methylation in large marine systems appears to peak in the upper waters below the mixed layer $(200-700 \mathrm{~m}$ ) (Cossa et al., 2009,2011; Sunderland et al., 2009). Inorganic Hg concentrations in waters at these depths were predicted by Sunderland and Mason (2007) to respond rapidly initially to reductions in direct atmospheric deposition, but require decades to reach steady state with lateral inputs from other ocean basins. Assuming that $\mathrm{MeHg}$ concentrations would respond relatively quickly to changes in $\mathrm{MeHg}$ production in these waters, fish $\mathrm{Hg}$ levels would similarly show an initial rapid response to changes in atmospheric deposition and a longer secondary phase response. Gulf regions with the potential for relatively rapid changes in $\mathrm{MeHg}$ production and concentrations (e.g. years to decadal scale) include locations where methylation in the water column (e.g. anoxic waters) or in a thin layer at the sediment water interface is important and supplied mostly by direct atmospheric $\mathrm{Hg}$ deposition. Harris et al. (this issue) predicted that this may be the case for example for some Florida coastal waters. 
Table 3

Leading ten species in the Gulf of Mexico recreational and commercial harvests for human consumption (MT=Metric tonnes).

\begin{tabular}{|c|c|c|c|c|c|}
\hline Species & Scientific name & Group & Harvest (MT) & Mean Hg (ppm) ${ }^{\mathrm{a}}$ & Sample size $(n)^{a}$ \\
\hline \multicolumn{6}{|c|}{ Recreational harvest (NMFS, 2010) } \\
\hline Spotted seatrout & Cynoscion nebulosus & Estuarine & 6,576 & 0.320 & 546 \\
\hline Red drum & Sciaenops ocellatus & Estuarine/coastal demersal & 5,397 & 0.497 & 594 \\
\hline Sheepshead & Archosargus probatocephalus & Estuarine/coastal demersal & 1,990 & 0.180 & 226 \\
\hline Red snapper & Lutjanus campechanus & Reef fish & 1,638 & 0.093 & 13 \\
\hline King mackerel & Scomberomorus cavalla & Coastal migratory pelagic & 1,507 & 1.085 & 385 \\
\hline Black drum & Pogonias cromis & Estuarine/coastal demersal & 1,302 & 0.443 & 233 \\
\hline Pinfish & Lagodon rhomboides & Estuarine/coastal demersal & 1,290 & 0.131 & 6 \\
\hline Groupers & family Serranidae & Reef fish & 1,215 & - & - \\
\hline Sand seatrout & Cynoscion arenarius & Estuarine & 1,084 & 0.475 & 99 \\
\hline Spanish mackerel & Scomberomorus maculatus & Coastal migratory pelagic & 889 & 0.527 & 204 \\
\hline \multicolumn{6}{|c|}{ Commercial harvest (NMFS, 2009) } \\
\hline White Shrimp & Litopenaeus setiferus & Estuarine/coastal demersal & 44,586 & 0.024 & 16 \\
\hline Brown Shrimp & Farfantepenaeus aztecus & Estuarine/coastal demersal & 35,864 & 0.033 & 14 \\
\hline Blue Crabs & Callinectes sapidus & Estuarine & 22,211 & 0.141 & 239 \\
\hline Eastern Oysters & Crassostrea virginica & Estuarine & 9,363 & 0.080 & 1,634 \\
\hline Mullet & family Mugil spp. & Estuarine/coastal demersal & 4,676 & 0.063 & 56 \\
\hline Pink Shrimp & Farfantepenaeus duorarum & Estuarine/coastal demersal & 3,207 & - & - \\
\hline Stone Crabs & Menippe mercenaria & Demersal & 2,769 & 1.360 & 3 \\
\hline Red Grouper & Epinephelus morio & Reef fish & 2,531 & 0.324 & 44 \\
\hline Black Drum & Pogonias cromis & Estuarine/coastal demersal & 1,836 & 0.443 & 233 \\
\hline Spiny Lobster & Panulirus argus & Estuarine/coastal demersal & 1,350 & - & - \\
\hline
\end{tabular}

${ }^{\mathrm{a}} \mathrm{Hg}$ data from US EPA (2003).

\section{MeHg bioaccumulation}

MeHg concentrations in fish and shellfish in the Gulf region vary depending on species, size, and conditions affecting $\mathrm{MeHg}$ supply and delivery through the food web. Table 3 shows the top ten species of fish or shellfish harvested recreationally and commercially for human consumption in the Gulf of Mexico, and associated $\mathrm{Hg}$ concentrations. The commercial harvest is much larger than the recreational harvest but is consumed both within and outside of the Gulf region. More than half of the commercial catch occurs within estuaries and in coastal waters within $5 \mathrm{~km}$ of shore (NMFS, 2009), dominated by invertebrates (shrimps, crabs, oysters) that are typically low in $\mathrm{Hg}$ concentrations. The recreational harvest includes a greater proportion of species with higher $\mathrm{Hg}$ concentrations than are typically harvested commercially (Table 3 ). Many datasets exist that characterize $\mathrm{Hg}$ in biota for the Gulf, and are further described in Appendix B.

\subsection{Are biota mercury concentrations higher in the Gulf?}

There is evidence that some fish species have higher $\mathrm{Hg}$ concentrations in the Gulf than in the adjacent Atlantic Ocean. Adams and McMichael (2007) reported that both king mackerel and Spanish mackerel from the eastern Gulf contain significantly higher concentrations of $\mathrm{Hg}$ in dorsal muscle than those from the southeastern U.S. Atlantic coast (king mackerel: 1.51 vs. $0.94 \mu^{g^{-1}}$ means). Other studies consistent with this finding include Glover et al. (2010), Katner et al. (2010) and Cai et al. (2007). Bluefish (Pomatotomus saltatrix) and common snook (Centropomus undecimalis) were also reported to have higher $\mathrm{Hg}$ concentrations in Gulf waters than in the Atlantic (Adams et al., 2003). The golden tilefish (Lopholatilus chamaeleonticeps), a deepwater (200-300 m) demersal species has similarly been found to have $\mathrm{Hg}$ concentrations in Gulf waters that are two to three-fold higher (Fig. 3) than concentrations observed from the U.S. Atlantic coast (Hall et al., 1978). By contrast, the migratory pelagic dolphinfish (Coryphaena hippurus) seems to have $\mathrm{Hg}$ concentrations no higher than conspecifics from the U.S. Atlantic coast or elsewhere within its range (Adams, 2009; Evans et al.,

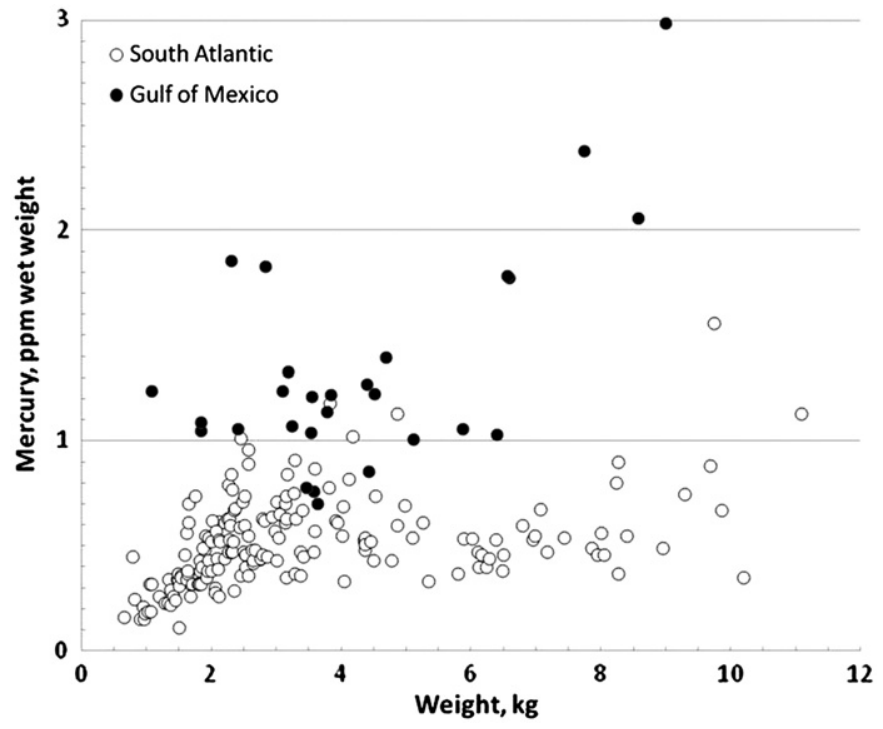

Fig. 3. Comparison of mercury concentrations in the golden tilefish as a function of weight in the Gulf of Mexico and U. S. Atlantic coasts.

Source: Hall et al. (1978).

unpubl.). Whether Gulf fish $\mathrm{Hg}$ concentrations are higher than other regions needs further study.

\subsection{Are there areas within the Gulf with elevated $\mathrm{MeHg}$ concentrations?}

Inter-estuarine differences in fish $\mathrm{Hg}$ concentrations are to be expected given the differences in potential $\mathrm{Hg}$ sources, watersheds, and physical and biogeochemical characteristics of estuaries. Ache et al. (2000) identified two estuarine areas within the Gulf as biota Hg "hotspots”. Lavaca Bay, Texas has local industrial contamination (Bloom et al., 1999; Gill et al., 1999), while eastern Florida Bay is within a national park with little industrial, urban, or agricultural $\mathrm{Hg}$ inputs. Marine and estuarine fishes in Florida Bay often accumulate higher concentrations of $\mathrm{MeHg}$ than in 
other areas of Florida (Evans and Crumley, 2005; Adams et al., 2003; Adams and Onorato, 2005). Current fish consumption advisories are more restrictive for a number of species in Florida Bay as compared to advisories for these same species in other Florida coastal waters, including crevalle jack, great barracuda, spotted seatrout, red drum, common snook, tripletail, and gray snapper (Lutjanus griseus) (FDOH, 2012). Lowery and Garrett (2005) found differences in fish $\mathrm{Hg}$ concentrations among four Gulf estuaries, but these differences were not consistent across all species studied. Within estuaries, declining fish $\mathrm{Hg}$ levels have been observed along increasing salinity gradients. In Mobile Bay, Farmer et al. (2010) found that upstream areas of the estuary's delta had higher $\mathrm{Hg}$ concentrations in flounders and largemouth bass than downstream, though still brackish, areas. Lange et al. (2011) recently reported finding a steep gradient in Hg levels along the Shark River estuary in Everglades National Park, with concentrations declining seaward in gray snappers: $0.45 \mu \mathrm{g} \mathrm{g}^{-1}$ at the upstream site, $0.15 \mu \mathrm{g} \mathrm{g}^{-1}$ midstream, and $0.05 \mu \mathrm{g} \mathrm{g}^{-1}$ at the mouth of the estuary.

In open Gulf waters, mixing should reduce $\mathrm{MeHg}$ concentration gradients observed in estuaries. Cai et al. (2007) did not find spatial differences in $\mathrm{Hg}$ levels in several offshore pelagic species sampled in Texas and Louisiana. Dolphinfish, a migratory pelagic species living offshore did not show an east/west Hg concentration difference. Biota from the northwestern and northeastern Gulf might be expected, however, to differ in $\mathrm{Hg}$ content because of the influence of the Mississippi River as a source of both $\mathrm{Hg}$ inputs (Rice et al., 2008; Harris et al., this issue) and nutrients that increase biological productivity (e.g. Dagg and Breed, 2003). Increased productivity can have competing effects on $\mathrm{MeHg}$, including increased microbial activity that could enhance methylation rates, and increased fish growth rates, that tend towards lower fish $\mathrm{Hg}$ concentrations. Golden tilefish caught west of the Mississippi River plume, for example, had Hg concentrations approximately 30\% higher on average than fish captured east of the plume, after adjustments for fish size (Lombardi and Evans, unpubl.). As in the case of spatial comparisons of the Gulf versus Atlantic, further effort should be made to assess within-Gulf geographic variations in fish tissue $\mathrm{Hg}$ levels, using existing databases with targeted monitoring to fill data gaps.

\subsection{How important are fish movements and migrations in redistributing $\mathrm{MeHg}$ ?}

Fish movement within and among habitats affects fish $\mathrm{MeHg}$ exposure, and has the potential to represent a vector to transport MeHg among Gulf regions. Marine species have many life-history strategies by which they move across temporal and spatial scales, including daily, tidal or seasonal relocation of home range, ontogenetic shifts in habitat use, spawning migrations, and dispersal and directed movement of planktonic early life stages (Pittman and McAlpine, 2003; Gillanders et al., 2003). Migrations of estuarydependent juveniles to adult habitats offshore (see Gillanders et al., 2003) and the diurnal vertical migration of zooplankton are among the most significant coordinated mass movements in oceans.

There is evidence of migrations of bluefin tunas, some billfishes, and king mackerel between the Gulf of Mexico and the Atlantic Ocean (Ortiz et al., 2003), and the Gulf has a high proportion of "estuarine dependent" species that migrate to adult habitats offshore. Examples include gag and other groupers as well as several species of snappers that move from estuarine or nearshore juvenile nursery grounds to offshore reefs as adults. Carbon, N, and S isotopes have been used in Florida Bay to track the migration of shrimp from estuarine nursery habitats to offshore feeding grounds (Fry et al., 1999). Although the effects of such movements on biota $\mathrm{MeHg}$ exposure and $\mathrm{MeHg}$ transport in the Gulf are largely unstudied, recent attention has been given to the potential importance of $\mathrm{Hg}$ biotransport in marine systems, in particular from estuaries out to coastal ocean (Fitzgerald et al., 2007; Chen et al., 2008,2009). Biotransport has also been documented for other regions and substances. Deegan (1993) estimated $5-10 \%$ of the total primary production of a Louisiana estuary was exported just in the form of menhaden, Brevoortia patronus. There are also numerous cases of biotransport of persistent organic pollutants as a result of large-scale synchronized movements of animals including fish, birds, and marine mammals (Merna, 1979; Ewald et al., 1998; Wania, 1998; Blais et al., 2005; Blais et al., 2007). Salmon were estimated to transport a substantial portion of a river's MeHg budget, over $1 \mathrm{~kg} \mathrm{yr}^{-1}$, to Bristol Bay, Alaska watersheds from the ocean (Zhang et al., 2001). Senn et al. (2010) recently concluded, however, that there was potentially a disconnect between the near coastal and oceanic food webs off Louisiana, based on the distributions of stable isotopes of $\mathrm{C}, \mathrm{N}$, and $\mathrm{Hg}$ in collected fish. Offshore, highly migratory species such as yellowfin tuna appear linked to a more phytoplankton-based food web and $\mathrm{MeHg}$ that has been subject to greater photo-degradation than nearshore species. These tuna are known to migrate between the Gulf of Mexico and the Atlantic Ocean.

\subsection{Are there different food webs in the Gulf supporting different $\mathrm{Hg}$ bioaccumulation?}

Fisheries production in open Gulf waters is likely to be supported by phytoplankton-based food webs, while terrestrial, seagrass, salt marsh and mangrove productivity, and benthic pathways are more important in some estuarine and nearshore waters. As discussed in Section 5.2, the Mississippi River introduces large quantities of nutrients that support high primary and secondary production and the largest fish harvests in the Gulf. These food-web differences can ultimately affect fish $\mathrm{MeHg}$ concentrations, as the largest single biomagnification step for $\mathrm{MeHg}$ is at the base of the food web (e.g. Wiener et al., 2003). Measurements of stable isotopes of $\mathrm{C}, \mathrm{N}$, and S in Gulf biota confirm geographic and habitat differences in food webs (Senn et al., 2010). Within Florida Bay, gradients in the importance of different primary producers in supporting fish and invertebrates are evident over even small spatial scales (Evans and Crumley, 2005; Chasar et al., 2005). The effects of these differences on $\mathrm{MeHg}$ bioaccumulation have not yet been fully evaluated. Existing datasets described in Appendix A may be useful in this regard, particularly those with isotopic data on nutrients and $\mathrm{Hg}$.

\section{Human exposure}

$\mathrm{MeHg}$ is a neurotoxin that affects the central nervous system in humans and can cause long-term delays in neurocognitive development of children (Mahaffey et al., 2011). Several studies have shown that other effects of MeHg exposure on adults may include cardiovascular impairment and endocrine disruption (Salonen et al., 2000,1995; Tan et al., 2009). The primary source of $\mathrm{MeHg}$ exposure for most North Americans is consumption of marine and estuarine fish (Mahaffey et al., 2011, 2009, 2004). The most recent $\mathrm{Hg}$ exposure study for U.S. women of childbearing age suggests that between $3 \%$ and $15 \%$ pregnant women have blood $\mathrm{Hg}$ concentrations that are high enough for fetal blood levels to exceed the US EPA's MeHg reference dose (safety standard), depending on whether concentrations of $\mathrm{MeHg}$ in umbilical blood are considered (Mahaffey et al., 2009). The same 
study showed that blood $\mathrm{Hg}$ levels in coastal residents are significantly elevated compared to the rest of the country.

Per-capita fish consumption in the Gulf of Mexico region (46 $\mathrm{g} \mathrm{day}^{-1}$ for fishers, $24.4 \mathrm{~g} \mathrm{day}^{-1}$ when adjusted for non-fish consumers) is elevated compared to the U.S. national average of $16.9 \mathrm{~g} \mathrm{day}^{-1}$ (Degner et al., 1994; US EPA, 2002). Mahaffey et al. (2009) showed that women of childbearing age in the Gulf of Mexico most commonly consume tuna, shrimp, salmon, and finfish like grouper and snapper at an average rate of 5.9 meals per month and $>8$ meals per month for Asian and Native Americans. Data from Imm et al. (2007) suggest that children consume fish at a similar frequency to their mothers (average 5.17 meals/month and $12 \%>8$ meals per month). Reported rates of fish consumption in the Gulf of Mexico region from the NHANES survey are higher than all other areas of the U.S. except the Atlantic coastal region (Mahaffey et al., 2009). Similarly, Warner (2007) reported significantly higher levels of $\mathrm{Hg}$ in hair from coastal residents and anglers in Alabama compared to residents from northern parts of the state.

Since $\mathrm{Hg}$ concentrations across fish species can vary by more than 100 -fold, data on both quantities and species consumed are needed to accurately estimate $\mathrm{MeHg}$ exposures. Many dietary surveys report the frequency of fish meals consumed but do not provide information on meal sizes or species, needed to estimate variability in $\mathrm{Hg}$ exposures (Karouna-Renier et al., 2008; Patch et al., 2005; Mahaffey et al., 2009; NRDC, 2010). Fish consumption rates reported from a survey by Degner et al. (1994), averaged across all demographic groups for the top 25 categories of fish consumed by Florida residents are shown in Fig. 4. Also shown are the respective fish $\mathrm{Hg}$ concentrations (measured as $\mathrm{THg}$ and assumed to be $\mathrm{MeHg}$ ) and the ranked contributions to overall $\mathrm{Hg}$ intake by residents. The data in Fig. 4 reflect the consumption of seafood items caught both within and outside the Gulf. Tuna, grouper, and snapper account for almost $60 \%$ of the $\mathrm{Hg}$ intake because of the large quantities of these fish consumed (Fig. 4B). Shrimp are the second most frequently consumed category of seafood in the Gulf but account for only slightly more than $2 \%$ of $\mathrm{Hg}$ intake because of low tissue $\mathrm{Hg}$ concentrations (Fig. 4). The relative contributions of different fish species to $\mathrm{Hg}$ exposure vary considerably across different demographic groups. For example, recreational fishers $\mathrm{Hg}$ exposures are dominated by species like red drum and spotted seatrout (Fig. 5) (Katner et al., 2011; Lincoln et al., 2011).

Lincoln et al. (2011) showed that recreational fishers and their families in Louisiana consume large quantities of fish harvested from the Gulf (74\% of total consumption) and that hair $\mathrm{Hg}$ concentrations in $40 \%$ of the population surveyed exceeded levels associated with the US EPA's reference dose for MeHg. These groups are therefore likely to be among the most vulnerable groups to effects associated with high levels of $\mathrm{MeHg}$ exposures (Imm et al., 2007; Lincoln et al., 2011; Sunderland et al., 2012). Improved data on the sources of fish consumed by Gulf state residents are needed to understand how human exposures to $\mathrm{Hg}$ will change with reductions in $\mathrm{Hg}$ inputs and fish $\mathrm{MeHg}$ levels. This information could also be used to better inform the public of existing risks and options to reduce risks.

\section{Conclusions}

The Gulf of Mexico has major commercial and recreational fisheries of national importance in the United States. Fish $\mathrm{Hg}$ concentrations are elevated in some species in the Gulf, including king mackerel, sharks, and tilefish. Fish consumption advisories for $\mathrm{Hg}$ are in place for all five Gulf states. Per-capita fish consumption in the Gulf is elevated compared to the U.S. national average. Swordfish have the highest $\mathrm{Hg}$ concentrations consumed by Floridians, but tuna, grouper, and snapper account for more
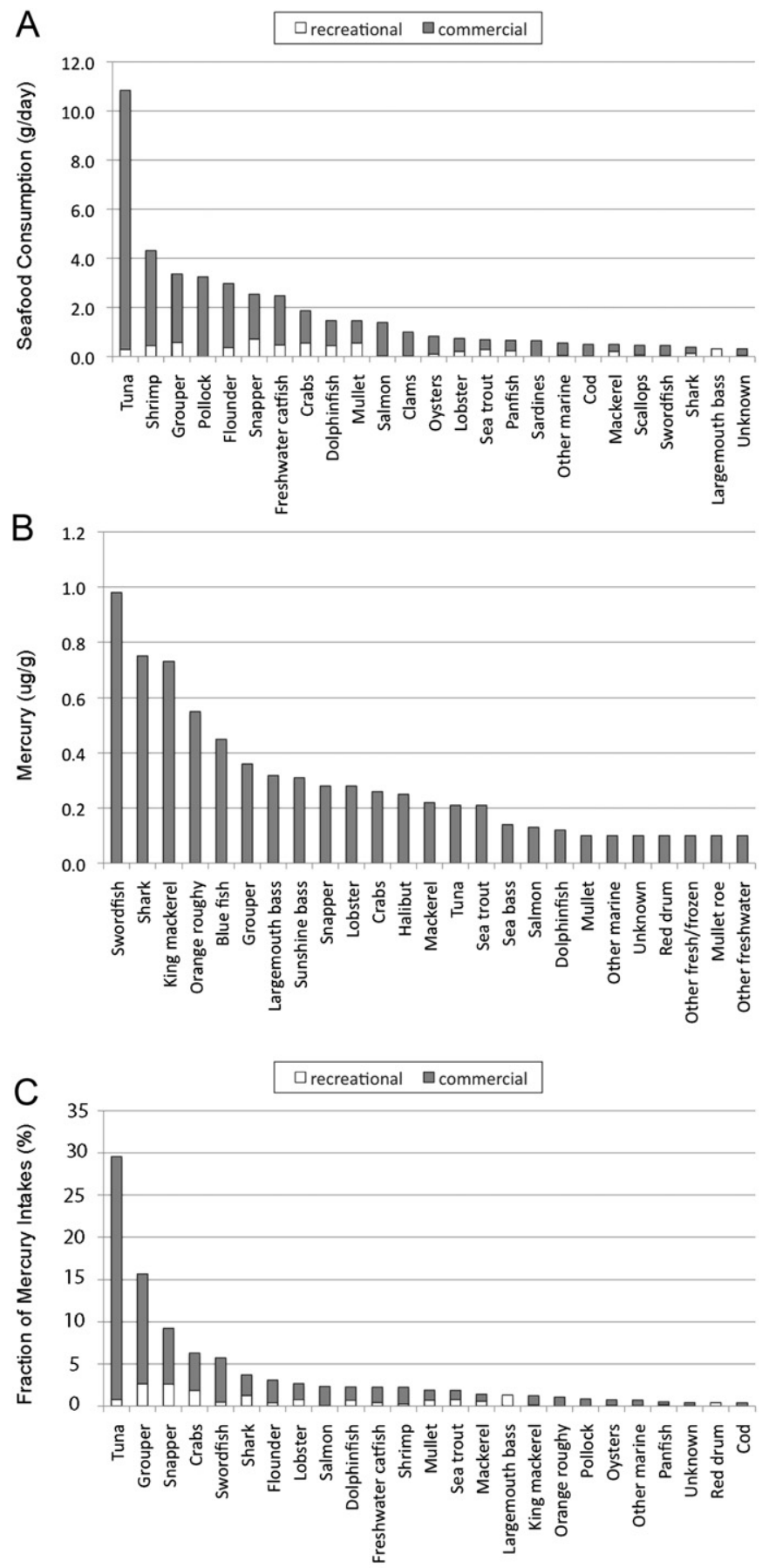

Fig. 4. Top 25 seafood categories for Florida residents per-capita: (A) seafood consumption, (B) mercury concentrations, and (C) mercury intakes. Seafood consumption data based on Degner et al. (1994) and fish mercury data are from Sunderland (2007) and Lowery and Garrett (2005). Mercury concentrations are not exclusive to the Gulf and include results from other regions.

than half of the $\mathrm{Hg}$ intake because of the larger quantities consumed. Because Gulf recreational fishers and family members consume greater quantities of Gulf fish than the national average, and because $\mathrm{Hg}$ levels can be elevated in these fish compared to other areas, they have a greater potential for increased $\mathrm{MeHg}$ exposure. This is supported by surveys of recreational fishers in the Gulf region showing high percentages of respondents exceeding the US EPA's reference dose for MeHg (Lincoln et al., 2011).

There is evidence that fish $\mathrm{Hg}$ concentrations in the Gulf are higher than in Atlantic waters for some but not all fish species. 
A

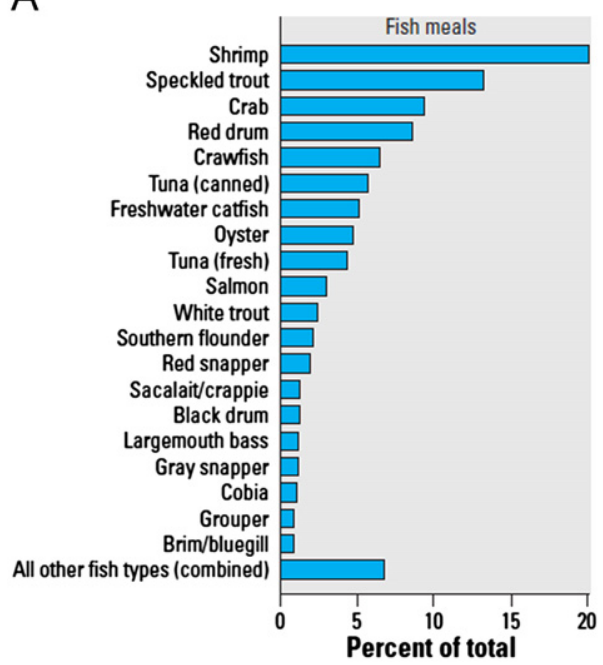

B

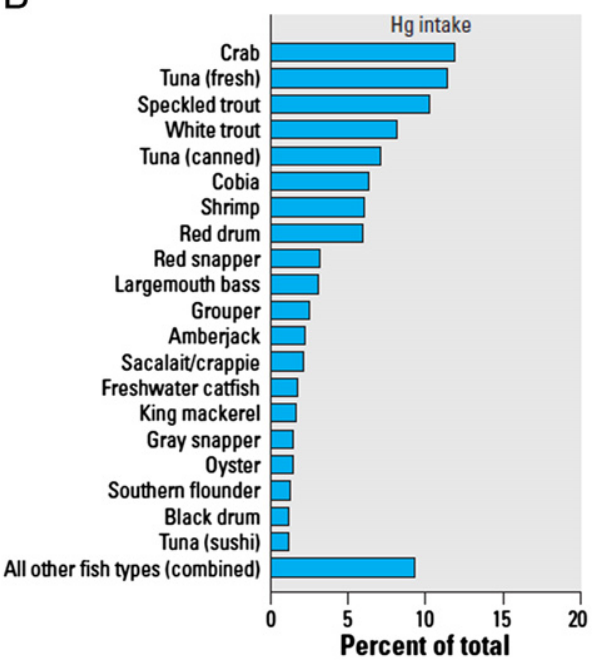

Fig. 5. Percent of total fish meals (A) and Hg intake (B) contributed by individual fish types to total intake across all Louisiana recreational anglers. From Lincoln et al. (2011).

Factors governing fish $\mathrm{Hg}$ levels in the Gulf of Mexico, and in oceans generally, are not adequately resolved. Atmospheric wet $\mathrm{Hg}$ deposition is elevated to the Gulf region in comparison to most other areas in the U.S., but the dominant source of $\mathrm{Hg}$ to the Gulf as a whole is estimated to be Atlantic inputs via the Loop Current. Redistribution of atmospheric, Atlantic and terrestrial $\mathrm{Hg}$ inputs to the Gulf occurs via water circulation but is underconstrained. Fundamental questions remain regarding where insitu methylation occurs and what trophic factors lead to high bioaccumulation factors in marine waters (high $\mathrm{MeHg}$ in some fish, generally low MeHg concentrations in surface waters).

\section{Future needs}

Our analysis reinforces the disparity between the high importance of the Gulf fishery and a limited understanding of factors controlling Gulf fish $\mathrm{Hg}$ levels and associated risks to humans. There has historically been an emphasis on studies of $\mathrm{Hg}$ in freshwater systems, partly because they are often more manageable in terms of size and complexity. Increased attention is now needed for $\mathrm{Hg}$ in marine systems generally, including the Gulf of Mexico. This need has been recognized for the Gulf of Mexico at a high level federally in the United States for several years (NSTC, 2004). Field data are needed to better describe $\mathrm{THg}$ and $\mathrm{MeHg}$ sources, sinks, and concentrations in estuaries, coastal and pelagic regions, including measurements in the water column, sediments, and lower food web. $\mathrm{Hg}$ data are essentially non-existent for $\mathrm{Hg}$ in open waters of the Gulf. Mexico and Cuba also border the Gulf of Mexico and a multinational effort is encouraged. Finally, to understand the link between Gulf fish $\mathrm{Hg}$ levels and human exposures, updated dietary survey data are needed for Gulf state coastal residents. The only statistically representative survey of Gulf of Mexico state residents was conducted in Florida in the 1990s (Degner et al., 1994) and few data are available for other Gulf states.

\section{Acknowledgments}

The authors would like to acknowledge the financial support of the Florida Department of Environmental Protection. NOAA provided research data on $\mathrm{Hg}$ cycling in Mobile Bay and fish tissue concentrations of $\mathrm{Hg}$ in the Gulf of Mexico. The Gulf of Mexico Alliance has also been supporting $\mathrm{Hg}$ science in the Gulf of Mexico, needed to accomplish the long term goals of this study. Dr. Jane Caffrey (University of West Florida) and Nishanth Krishnamurthy (Florida State University) provided wet deposition data from the Pensacola Atmospheric $\mathrm{Hg}$ Study and $\mathrm{Hg}$ wet deposition data were obtained from the NADP/MDN network. Atmospheric modeling was supported, in part, by the Electric Power Research Institute (EPRI) and the Florida Electric Power Coordinating Group (FCG). This publication was made possible in part by NIH Grant number P42 ES007373 from the National Institute of Environmental Health Sciences.

\section{Appendix A. Development of atmospheric Hg deposition model scenarios}

The version of the GEOS-Chem global biogeochemical model applied here (Holmes et al., 2010) used the Streets et al. (2009) global anthropogenic emission inventory for 2006, and the spatial pattern from the GEIA 2000 inventory (Pacyna et al., 2006). The simulation with AMSTERDAM (also known as CMAQMADRID-APT) was conducted for calendar year 2002 and used speciated $\mathrm{Hg}$ emissions estimated for (1) U.S. coal-fired electric generating units from 2002 Continuous Emissions Monitoring System (CEMS) heat input data and known coal quality and controls information and (2) for other US sources from US EPA's, 2001 Clean Air Hg Rule (CAMR) modeling which reflected a late 1990s/early 2000s time frame (US EPA, 2005). Boundary conditions for speciated $\mathrm{Hg}$ were obtained from GEOS-Chem modeling for 2002. The REMSAD simulation used the USA emissions data utilized by the US EPA in the CAMR modeling, with updates to key emitters to better match the 2001 modeling year. Further information on REMSAD emissions can be found in "Emissions Inventory and Emissions Processing for the Clean Air Hg Rule (CAMR)" (US EPA, 2005; Atkinson et al., 2008). REMSAD boundary conditions consisted of boundary layer concentrations of inorganic $\mathrm{Hg}(\mathrm{II})$ and $\mathrm{Hg}(0)$ from three global models: CTM (Seigneur et al., 2001), GRAHM, (Dastoor and Larocque, 2004) and GEOS-Chem.

The AMSTERDAM and REMSAD models used meteorological inputs that predicted excessive rainfall over the USA; consequently, these models also over-predicted wet $\mathrm{Hg}$ deposition when compared to MDN sites in the USA (27\% and $33 \%$, 
Table B1

Major Gulf-wide compilations of mercury concentrations in biota.

\begin{tabular}{lrcll}
\hline Reference & Samples & Species & Dates & Comments \\
\hline Hall et al. (1978) & 1,699 & 53 & 1975 & Includes invertebrates \\
Ache et al. (2000) & 26,322 & 181 & $1990-2000$ & Includes invertebrates \\
US EPA (2003) & 7,224 & 108 & $1990-2001$ & Includes invertebrates \\
Lowery and Garrett (2005) & 1,660 & 24 & $2003-2004$ & Estuarine, reef, and pelagics \\
Kimbrough et al. (2008) & 10,051 & 1 & $1986-2009$ & Estuarine invertebrate \\
\hline
\end{tabular}

respectively). Modeled wet deposition fluxes over the Gulf of Mexico were subsequently adjusted by those percentages to match the observed wet deposition from MDN sites along the Gulf coast more closely (Table 2). GEOS-Chem simulations did not exhibit the same tendency to overestimate wet $\mathrm{Hg}$ deposition and were not adjusted.

Differences among the model estimates of THg deposition may be partly due to the different emission inventories in each model. All three models predicted significant seasonal variability in the wet deposition of $\mathrm{Hg}$, mostly driven by summertime increases in rainfall. Approximately $60-70 \%$ of the annual wet deposition is predicted to occur between May-October. These predictions are consistent with data from the NADP $\mathrm{Hg}$ Deposition Network (MDN) that show maximum wet deposition rates ( $\sim 60-75 \%)$ during the May through October "wet season" at two active MDN sites (AL24 and F05) (Table 2). Data from the three Pensacola Atmospheric Hg Study sites (PAMS) showed an average annual wet deposition from 2005 through 2010 of $15.5 \mu \mathrm{g} \mathrm{m}^{-2} \mathrm{yr}^{-1}$, with $64 \%$ depositing from May through October (Table 2).

\section{Appendix B. Mercury in biota databases}

Many datasets exist characterizing $\mathrm{Hg}$ concentrations in biota of the Gulf of Mexico. The majority of these data are for edible seafood species from monitoring programs in U.S. waters, designed to assess the need for consumption advisories. Little published information on Gulf biota $\mathrm{Hg}$ concentrations was identified for the two nations that border the southern Gulf, Mexico and Cuba. Existing data collectively permit a preliminary assessment of what species have the highest $\mathrm{Hg}$ concentrations and therefore present greater risk to consumers. To a lesser extent, the data suggest geographic differences in $\mathrm{Hg}$ concentrations that can help to identify hot spots of concern. Extensive maps document the distribution of harvested species within the Gulf and general patterns of movement and migration (NOAA, 1985). Finally, there is information available for many food webs in the Gulf that can be useful to help infer the transfer of $\mathrm{MeHg}$ from water and sediments to primary producers and subsequent biomagnification to higher trophic levels. Hg data for these lower trophic level organisms, especially invertebrates, are rare, however for the Gulf and marine systems generally.

Table B1 lists the major published Gulf-wide data sets on $\mathrm{Hg}$ in Gulf biota. Several are compilations of original data published elsewhere. The US EPA also maintains a fish consumption advisory database documenting $\mathrm{Hg}$ and other contaminant concentrations in biota used by the states, tribes, and the Federal Government to justify consumption advisories. Smaller, area and species-specific published studies include pelagic fish off of Texas and Louisiana (Cai et al., 2007), gamefish and forage fish from Florida Bay (Evans and Crumley, 2005), recreational gamefish off of Alabama (Warner and Savitz, 2006), snappers off Louisiana (Bank et al., 2007; Wells et al., 2008), and groupers and seabasses off Florida (Tremain and Adams, in press). Adams et al. (2003) summarized a large body of $\mathrm{Hg}$ concentrations in marine species along Florida's Gulf coast. Other important unpublished datasets include those of state monitoring programs (e.g. Texas Department of Health, 1998).

A broad array of isotope studies for nutrients also exists in the Gulf (Evans and Crumley, 2005; Bank et al., 2007; Cai et al., 2007; Akin and Winemiller, 2008; Senn et al., 2010), some also measuring $\mathrm{Hg}$, that would help to distinguish features among food webs and test the validity of food web models such as EcoPath and NETWRK (Vidal and Pauly, 2004).

Finally, fish $\mathrm{Hg}$ databases typically report on $\mathrm{THg}$ concentrations rather than $\mathrm{MeHg}$ under the assumption that most $\mathrm{Hg}$ in fish muscle is methylated. However, with invertebrates, and some lower trophic level fish, the percentage of $\mathrm{THg}$ that is $\mathrm{MeHg}$ has been found to be highly variable (Thera, 2011). Careful consideration should be given to this issue when using datasets characterizing $\mathrm{Hg}$ levels in aquatic biota.

\section{References}

Ache, B., Boyle, J.D., Morse, C.E., 2000. Survey of the Occurrence of Hg in the Fisheries Resources of the Gulf of Mexico. Prepared by Battelle for the U.S. EPA Gulf of Mexico Program, Stennis Space Center, Mississippi, USA.

Adams, D.H., 2009. Consistently low Hg concentrations in dolphinfish, Coryphaena hippurus, an oceanic pelagic predator. Environ. Res. 109, 697-701.

Adams, D.H., McMichael Jr., R.H., 2007. Hg in king mackerel, Scomberomorus cavalla, and Spanish mackerel, S. maculatus, from waters of the south-eastern USA: regional and historical trends. Mar. Freshwater Res. 58, 187-193.

Adams, D.H., Onorato, G.V., 2005. Hg concentratins in red drum, Sciaenops ocellatus, from estuarine and offshore waters of Florida. Mar. Pollut. Bull. 50, 291-300.

Adams, D.H., McMichael, R.H. Jr., Henderson, G.E., 2003. Hg Levels in Marine and Estuarine Fishes of Florida 1989-2001 FMRI Technical Report TR-9 s Edition, Revised, p. 58

Akin, S., Winemiller, K.O., 2008. Body size and trophic position in a temperate estuarine food web. Acta Oecologica 33, 144-153.

Atkinson, D., Chemerys, R., Myers, T., Wei, Y., Hudischewskyj, B., Haney, J., Douglas, S., 2008. Model-Based Analysis and Tracking of Airborne Mercury Emissions to Assist in Watershed Planning. Document posted at: <http:// www.epa.gov/owow/tmdl/techsupp.html > (accessed 21.09.11).

Bank, M.S., Chesney, E., Shine, J.P., Maage, A., Senn, D.B., 2007. Mercury bioaccumulation and trophic transfer in sympatric snapper species from the Gulf of Mexico. Ecol. Appl. 17, 2100-2110.

Baskaran, M., Santschi, P.H., Guo, T., Bianchi, S., Lambert, C., $1996 .{ }^{234} \mathrm{Th}:{ }^{238} \mathrm{Su}$ disequilibria in the Gulf of Mexico: the importance of organic matter and particle concentration. Cont. Shelf Res. 16, 353-380.

Blais, J.M., Macdonald, R.W., Mackey, D., Webster, E., Harvey, C., Smol, J.P., 2007. Biologically mediated transport of contaminants to aquatic systems. Environ. Sci. Technol. 41, 1075-1084.

Blais, J.M., Kimpe, L.E., McMahon, D., Keatley, B.E., Mallory, M.L., Douglas, M.S.V., Smol, J.P., 2005. Arctic seabirds transport marine-derived contaminants. Science 309, 445.

Bloom, N.S., Gill, G.A., Cappellino, S., Dobbs, C., McShea, L., Driscoll, C., Mason, R., Rudd, J., 1999. Speciation and cycling of mercury in Lavaca Bay, Texas, sediments. Environ. Sci. Technol. 33, 7-13.

Cai, Y., Rooker, J.R., Gill, G.A., Turner, J.P., 2007. Bioaccumulation of $\mathrm{Hg}$ in pelagic fishes from the northern Gulf of Mexico. Can. J. Fish. Aquat. Sci. 64, 458-469.

Carranza-Edwards, A., Rosales-Hoz, L., Monreal-Gómez, A., 1993. Suspended sediments in the southeastern Gulf of Mexico. Mar. Geol. 112 (1-4), 257-269, http://dx.doi.org/10.1016/0025-3227(93)90172-R.

Chasar, L.C., Chanton, J.P., Koenig, C.C., Coleman, F.C., 2005. Evaluating the effect of environmental disturbance on the trophic structure of Florida Bay, U.S.A.: Multiple stable isotope analyses of contemporary and historical specimens. Limnol. Oceanogr. 50, 1059-1072.

Chen, C.Y., Dionne, M., Mayes, B.M., Ward, D.M., Sturup, S., Jackson, B.P., 2009. Mercury bioavailability and bioaccumulation in estuarine food webs in the Gulf of Maine. Environ. Sci. Technol. 43, 1804-1810. 
Chen, C., Amirbahman, A., Fisher, N., Harding, G., Lamborg, C., Nacci, D., Taylor, D., 2008. Methylmercury in marine ecosystems: spatial patterns and processes of production, bioaccumulation, and biomagnification. EcoHealth 5, 399-408.

Cossa, D., Heimburger, L.-E., Lannuzel, D., Rintoul, S.R., Butler, E.C.V., Bowie, A.R., Averty, B., Watson, R.J., Remenyi, T., 2011. Mercury in the Southern Ocean. Geochim. Cosmochim. Acta 75, 4037-4052.

Cossa, D., Averty, B., Pirrone, N., 2009. The origin of methylmercury in open Mediterranean waters. Limnol. Oceanogr. 54, 837-844.

Dagg, M.J., Breed, G.A., 2003. Biological effects of Mississippi River nitrogen on the northern gulf of Mexico-a review and synthesis. J. Mar. Syst. 43, 133-152.

Dastoor, A.P., Larocque, Y., 2004. Global circulation of atmospheric Hg: a modeling study. Atmos. Environ. 38, 147-161.

Deegan, L.A., 1993. Nutrient and energy transport between estuaries and coastal marine ecosystems by fish migration. Can. J. Fish. Aquat. Sci. 50, 74-79.

Degner, R., Adams, C., Moss, S., Mack, S., 1994. Per capita fish and shellfish consumption in Florida. In: F. D. O. E. (Ed.), Protection. Florida Agricultural Market Research Center, Gainsville, FL.

Delaune, R.D., Gambrell, R.P., Jugsujinda, A., Devai, I., Hou, A., 2008. Total Hg, methyl $\mathrm{Hg}$ and other toxic heavy metals in a northern Gulf of Mexico estuary: Louisiana Pontchartrain basin. J. Environ. Sci. Health Part A 43, 1006-1015, http://dx.doi.org/10.1080/10934520802059839.

Del Castillo, C.E., Gilbes, F., Coble, P.G., Muller-Karger, F.E., 2000. On the dispersal of riverine colored dissolved organic matter over the West Florida Shelf. Limnol. Oceanogr. 45, 1425-1432.

Evans, D.W., Crumley, P.H., 2005. Hg in Florida Bay fish: spatial distribution of elevated concentrations and possible linkages to Everglades restoration. Bull. Mar. Sci. 77, 321-345.

Ewald, G., Larsson, P., Linge, H., Okla, L., Szarzi, N., 1998. Biotransport of organic pollutants to an inland Alaska lake by migrating sockeye salmon (Oncorhynchus nerka). Arctic 51, 40-47.

Farmer, T.M., Wright, R.A., DeVries, D.R., 2010. Hg concentration in two estuarine fish populations across a seasonal salinity gradient. Trans. Am. Fish. Soc. 139, 1896-1912.

FDOH, 2012. Florida Department of Health. Your Guide to Eating Fish Caught in Florida. Tallahassee, FL. 〈http://doh.state.fl.us/floridafishadvice/2012-5Bro chure.pdf $\rangle$ (accessed 09.09.11)

Fitzgerald, W.F., Lamborg, C.H., Hammerschmidt, C.R., 2007. Marine biogeochemical cycling of mercury. Chem. Rev. 107, 641-662.

Fitzgerald, W.F., Engstrom, D.R., Mason, R.P., Nater, E.A., 1997. The case for atmospheric mercury contamination in remote areas. Environ. Sci. Technol. $32,1-7$.

Francesconi, K.A., Lenanton, R.C.J., Caputi, N., Jones, S., 1997. Long-term study of mercury concentrations in fish following cessation of a mercury-containing discharge. Mar. Environ. Res. 43, 27-40.

Fry, B., Mumford, P.L., Robblee, M.B., 1999. Stable isotope studies of pink shrimp (Farfantepenaeus duorarum Burkenroad) migrations on the southwestern Florida shelf. Bull. Mar. Sci. 65 (2), 419-430.

Gill, G.A., Bloom, N.S., Cappellino, S., Driscoll, C.T., Dobbs, C., McShea, L., Mason, R., Rudd, J.W.M., 1999. Sediment-water fluxes of mercury in Lavaca Bay, Texas. Environ. Sci. Technol. 33, 663-669.

Gillanders, B.M. Able, K.W. Brown, J.A., Egoleston, D.B. Sheridan, P.F, 2003. Evidence of connectivity between juvenile and adult habitats for mobile marine faunas: an important component of nurseries. Mar. Ecol. Prog. Ser. 247, 281-295.

Gilmour, C.C., Henry, E.A., Mitchell, R., 1992. Sulfate stimulation of mercury methylation in freshwater sediments. Environ. Sci. Technol. 1092 (26), 2281-2287.

Glover, J.B., Domino, M.E., Altman, K.C., Dillman, J.W., Castleberry, W.S., 2010. Mercury in South Carolina Fishes, USA. Ecotoxicology 19, 781-795, http://dx. doi.org/10.1007/s10646-009-0455-6.

Goni, M.A., Gordon, E.S., Monacci, N.M., Clinton, R., Gisewhite, R., Allison, M.A., Kineke, G., 2006. The effect of Hurricane Lili on the distribution of organic matter along the inner Louisiana shelf (Gulf of Mexico, USA). Cont. Shelf Res. 26, 2260-2280.

Guo, L., Santchi, P.H. Warnken, K.W., 1995. Dynamics of dissolved organic carbon (DOC) in oceanic environments. Limnol. Oceanogr. 40, 1392-1403.

Hall, R.A., Zook, E.G., Meaburn, G.M., 1978. National Marine Fisheries Service Survey of Trace Elements in the Fishery Resource. NOAA Technical Report NMFS SSRF-721 Washington D. C, p. 313.

Hammerschmidt, C.R., Fitzgerald, W.F., 2004. Geochemical controls on the production and distribution of methylmercury in near-shore marine sediments. Environ. Sci. Technol. 38, 1487-1495.

Harris, R.C., Pollman, C., Hutchinson, D., Landing, W., Axelrad, D., Morey, S.L., Dukhovskoy, D., Vijayaraghavan, K., A screening model analysis of $\mathrm{Hg}$ sources, fate and bioaccumulation in the Gulf of Mexico. Environ. Res., http://dx.doi. org/10.1016/j.envres.2012.08.013, this issue.

Harris, R.C., Rudd, J.W.M., Amyot, M., Babiarz, C.L., Beaty, K.G., Blanchfield, P.J., Bodaly, R.A., Branfireun, B.A., Gilmour, C.C., Graydon, J.A., Heyes, A., Hintelmann, H., Hurley, J.P., Kelly, C.A., Krabbenhoft, D.P., Lindberg, S.E., Mason, R.P., Paterson, M.J., Podemski, C.L., Robinson, A., Sandilands, K.A., Southworth St., G.R. Louis, V.L., Tate, M.T., 2007. Whole-ecosystem study shows rapid fish-mercury response to changes in mercury deposition. Proc. Natl. Acad. Sci. USA 104, 16586-16591.

Heimbürger, L.E., Cossa, D., Marty, J.C., Migon, C., Averty, B., Dufour, A., Ras, J., 2010. Methylmercury distributions in relation to the presence of nano- and picophytoplankton in an oceanic water column (Ligurian Sea, North-western Mediterranean). Geochim. Cosmochim. Acta 74, 5549-5559.

Herrin, R.T., Lathrop, R.C., Gorski, P.R., Andren, A.W., 1998. Hypolimnetic methylmercury and is uptake by plankton during fall destratification: a key entry point of mercury into lake food chains? Limnol. Oceanogr. 43 (7), $1476-1486$

Herut, B.H., Hornung, N.K., Cohen, Y., 1996. Environmental relaxation in response to reduced contaminant input: the case of mercury pollution in Haifa Bay, Israel. Mar. Pollut. Bull. 32, 366-373.

Holmes, C.D., Jacob, D.J., Corbitt, E.S., Mao, J., Yang, X., Talbot, R., Slemr, F., 2010 Global atmospheric model for mercury including oxidation by bromine atoms Atmos. Chem. Phys. 10, 12037-12057.

Hollweg, T.A., Gilmour, C.C., Mason, R.P., 2009. Methylmercury production in sediments of Chesapeake Bay and the mid-Atlantic continental margin. Mar. Chem. 114, 86-101.

Imm, P., Knobeloch, L., Anderson, H., 2007. Maternal recall of children's consumption of commercial and sport-caught fish: findings from a multi-state study. Environ. Res. 103, 198-204.

Kannan, K., Smith Jr., R.G., Lee, R.F., Windom, H.L., Heitmuller, P.T., Macauley, J.M. Summers, J.K., 1998. Distribution of total mercury and methylmercury in water, sediment, and fish from South Florida Estuaries. Arch Environ Contam Toxicol 34, 109-118.

Karouna-Renier, N., Rao, K., Lanza, J., Rivers, S., Wilson, P., Hodges, D., Levine, K, Ross, G., 2008. Mercury levels and fish consumption practices in women of child-bearing age in the Florida Panhandle. Environ. Res. 108, 320-326.

Katner, A., Ogunyinka, E., Sun, M.-H., Soileau, S., Lavergne, D., Dugas, D., Suffet, M., 2011. Fishing, fish consumption and advisory awareness among Louisiana's recreational fishers. Environ. 111, 1037-1045.

Katner, A., Sun, M.H., Suffet, M., 2010. An evaluation of mercury levels in Louisiana fish: trends and public health issues. Sci. Total Environ. 408, 5707-5714.

Kennicut, M.C., Schroeder, W.W., Brooks., J.M., 1995. Temporal and spatial variations in sediment characteristics on the Mississippi-Alabama continental shelf. Cont. Shelf Res. 15 (1), 1-18.

Kimbrough, K.L., Johnson, W.E., Lauenstein, G.G., Christensen, J.D., Apeti, D.A., 2008. An Assessment of Two Decades of Contaminant Monitoring in the Nation's Coastal Zone, 74. NOAA Technical Memorandum NOS NCCOS, Silver Spring, MD. (p. 105).

Knightes, C.D., 2008. Development and test application of a screening-level mercury fate model and tool for evaluating wildlife exposure risk for surface waters with mercury-contaminated sediments (SERAFM). Environ. Model. Software 23, 495-510.

Krabbenhoft, D., Tate, M., Harris, R., Olson, M., DeWild, J., Olund, S., 2006. Mercury mass fluxes from the lake 658 watershed. Abstract from a Presentation at the 8th International Conference on Mercury as Global Pollutant, August 2006, Madison, Wisconsin, USA

Lamborg, C.H., Von Damm, K.L., Fitzgerald, W.F., Hammerschmidt, C.R., Zierenberg, R. 2006. Mercury and monomethylmercury in fluids from Sea Cliff submarine hydrothermal field, Gorda Ridge. Geophys. Res. Lett. 33, L17606, http://dx.doi. org/10.1029/2006GL026321.

Lange, T.R., Rumbold, D.G., Krabbenhoft, D.P., Bergamaschi B.A., Aiken G.R., Fish Hg bioaccumulation along a salinity gradient in the Shark River, Everglades National Park, Florida, USA. Abstract from 10th International Conference on Hg as a Global Pollutant. Halifax, Nova Scotia, Canada. July 24-29, 2011.

Lincoln, R., Shine, J., Chesney, E., Vorhees, D.J., Grandjean, P., Senn, D.B., 2011. Fish consumption and mercury exposure among Louisiana recreational anglers. Environ. Health Perspect. 119, 245-251.

Liu, B., Schaider, L.A., Mason, R.P., Bank, M.S., Rabalais, N.N., Swarzenski, P.W Shine, J.P., Hollweg, T., Senn, D.B., 2009. Disturbance impacts on mercury dynamics in northern Gulf of Mexico sediments. J. Geophys. Res. 114, G00C07, http://dx.doi.org/10.1029/2008JG000752.

Loubere, P., Gary, A., Lagoe, M., 1993. Sea-bed Biogeochemistry and benthic foraminiferal bathymetric zonation on the slope of the northwest Gulf of Mexico. PALAIO 8, 439-449.

Lowery, T., Garrett, E.S., 2005. Synoptic Survey of THg in Recreational Finfish of the Gulf of Mexico, NOAAFisheries, Office of Sustainable Fisheries, National Seafood Inspection Laboratory, Silver Spring, MD.

Mahaffey, K.R., Sunderland, E., Chan, H.M., Choi, A.L., Grandjean, P., Marien, K. Oken, E., Sakamoto, M., Schoeny, R., Weihe, P., Yan, C.H., Yasutake, A., 2011. Balancing the benefits of $n-3$ polyunsaturated fatty acids and the risks of methylmercury exposure from fish consumption. Nutr. Rev. 69, 493-508.

Mahaffey, K., Clickner, R., Jeffries, R., 2009. Adult women's blood mercury concentrations vary regionally in USA: association with patterns of fish consumption (NHANES 1999-2004). Environ. Health Perspect. 117, 47-53.

Mahaffey, K.R., Clickner, R.P., Bodurow, C.C., 2004. Blood organic mercury and dietary mercury intake: National Health and Nutrition Examination Survey, 1999 and 2000. Environ. Health Perspect. 112, 562-670.

Mason, R.P., Choi, A.L., Fitzgerald, W.F., Hammerschmidt, C.R., Lamborg, C.H. Soerensen, A.L., Sunderland, E.M. Mercury biogeochemical cycling in the ocean and policy implications. Environ. Res., http://dx.doi.org/10.1016/j.envres.2012. 03.013, this issue.

Mergler, D., Anderson, H.A., Chan, L.H.M., Mahaffey, K.R., Murray, M., Sakamoto, M., Stern, A.H., 2007. Methylmercury exposure and health effects in humans: a worldwide concern. Ambio 36 (1), 3-11.

Merna, J.W., 1979. Introduction of Chlorinated Hydrocarbons into Stream Fishes by Spawning Salmon, Fish Res. Rep. No. 1878, Michigan Department of Natura Resources, Lansing, MI, p. 25. 
Morey, S.L., Zavala-Hidalgo, J., O’Brien, J.J., 2005. The seasonal variability of continental shelf circulation in the northern and western Gulf of Mexico from a high-resolution numerical model, in Circulation of the Gulf of Mexico: Observations and Models, Geophys. Mongr. Ser. 161, edited by W. Sturges and A. Lugo-Fernandez, AGU, Washington, DC, 〈http://dx.doi.org/10.1029/ 161GM16>.

Munthe, J., Bodaly, R.A., Branfireun, B., Driscoll, C.T., Gilmour, C.C., Harris, R., Horvat, M., Lucotte, M., Malm, O., 2007. Recovery of mercury-contaminated fisheries. Ambio 36, 33-44.

Munthe, J., Hultberg, H., 2004. Mercury and methylmercury in runoff from a forested catchment: concentrations, fluxes, and their response to manipulations. Water Air Soil Pollut. Focus 4, 607-618.

Neff, J.M., 2002. Fates and Effects of Mercury From Oil and Gas Exploration and Production Operations in the Marine Environment. Prepared for American Petroleum Institute.

NMFS, 2010. Recreational Fishery Statistics Catch Snapshot Query. 〈http://www. st.nmfs.noaa.gov/st1/recreational/queries/catch/snapshot.html $\rangle$.

NMFS, 2009. U.S. Landings by Distance from Shore. 〈http://www.st.nmfs.noaa. gov/st1/commercial/landings/ds_8850_bystate.html $\rangle$ (accessed 21.09.11).

NMFS, Fisheries of the United States, 2006. National Marine Fisheries Service, Office of Science and Technology. National Ocean and Atmospheric Admnistration, Silver Spring, Maryland. (p. 119).

NOAA, 2011. Fisheries of the United States 2010. U.S. Department of Commerce, National Oceanic and Atmospheric Administration, National Marine Fisheries Service, Silver Spring, Maryland. (p. 118) (accessed 09.09.11)<http://www.st. nmfs.noaa.gov/st1/fus/fus10/FUS_2010.pdf $>$.

NOAA, 1985. Gulf of Mexico Coastal and Ocean Zones Strategic Assessment: Data Atlas. National Oceanic and Atmospesheric Administration. Office of Oceanography and Marine Assessment.

NRDC, 2010. Gulf Coast Seafood Consumption Survey. National Resources Defense Council. (accessessed 21.09.11)<http://docs.nrdc.org/health/files/hea_10120702a. pdf $>$.

NSTC, 2004. Methylmercury in the Gulf of Mexico: State of Knowledge and Research Needs. Report of the National Science and Technology Council Committee on the Environment and Natural Resources. Interagency Working Group on Methylmercury. June 2004.

Oken, E., Choi, A.L., Karagas, M.R., Mariën, K., Rheinberger, C.M., Schoeny, R., Sunderland, E., Korrick, S., 2012. Which fish should I eat? Perspectives Influencing Fish Consumption Choices. Environ Health. Perspect. 120 (6), 790-798.

Ortiz, M., Prince, E.D., Serafy, J.E., Holts, D.B., Davy, K.B., Pepperell, J.G., Lowery, M.B., Holdsworth, J.C., 2003. Global overview of the major constituent-based billfish tagging programs and their results since 1954. Mar. Freshwater Res. 54, 489-507

Pacyna, E., Pacyna, J., Steenhuisen, F., Wilson, S., 2006. Global anthropogenic mercury emission inventory for 2000. Atmos. Environ. 40, 4048-4063.

Parks, J., Hamilton, A., 1987. Accelerating the recovery of the mercury contaminated Wabigoon English River System. Hydrobiologia 149, 159-188.

Patch, S., Maas, R., Sergent, K., 2005. An Investigation of Factors Related to Levels of Mercury in Human Hair. Technical Report 01-150. Environmental Quality Institute, University of North Carolina, Asheville, October 2005

Pittman, S.J., McAlpine, C.A., 2003. Movements of marine fish and decapod crustaceans: process, theory and application. Adv. Mar. Biol. 44, 205-294.

Rice, G.E., Senn, D.B., Shine, J.P., 2008. Relative importance of atmospheric and riverine mercury sources to the northern Gulf of Mexico. Environ. Sci. Technol 43, 415-422, http://dx.doi.org/10.1021/es800682b.

Salonen, J.T., Seppanen, K., Lakka, T.A., Salonen, R., Kaplan, G., 2000. Mercury accumulation and accelerated progression of carotid atherosclerosis: a population based prospective 4-year follow-up study in men in eastern Finland. Atherosclerosis 148, 265-273.

Salonen, J.T., Seppänen, K., Nyyssönen, K., Korpela, H., Kauhanen, J., Kantola, M. Tuomilehto, J., Esterbauer, H., Tatzber, F., Salonen, R., 1995. Intake of mercury from fish, lipid peroxidation, and the risk of myocardial infarction and coronary, cardiovascular, and any death in eastern finnish men. Circulation 91, 645-655

Scudder, B.C., Chasar, L.C., Wentz, D.A., Bauch, N.J., Brigham, M.E., Moran, P.W., Krabbenhoft, D.P., 2009. Mercury in Fish, Bed Sediment, and Water from Streams Across the United States, 1998-2005. National Water-Quality Assessment Program. Toxic Substances Hydrology Program. Scientific Investigation Report 2009-5109. U.S. Department of the Interior. U.S. Geological Survey.

Seigneur, C., Karamchandani, P., Lohman, K., Vijayaraghavan, K., Shia, R.-L., 2001. Multiscale modeling of the atmospheric fate and transport of Hg. J. Geophys. Res. 106 (D21), 27,795-27,809.

Senn, D.B., Chesney, E.J., Blum, J.D., Bank, M.S., Maage, A., Shine, A.P., 2010. Stable isotope $(\mathrm{N}, \mathrm{C}, \mathrm{Hg}$ ) study of $\mathrm{MeHg}$ sources and trophic transfer in the Northern Gulf of Mexico. Environ. Sci. Technol. 44, 1630-1637.

Solomon, S., Qin, D., Manning, M., Chen, Z., Marquis, M., Avery, K.B., Tignor, M., Miller H.L. (Eds.). 2007. Contribution of Working Group I to the Fourth Assessmen Report of the Intergovernmental Panel on Climate Change, 2007. Chapter 5.4.2.3 Ocean Acidification by Carbon Dioxide, Cambridge University Press, Cambridge, United Kingdom and New York, NY, USA. 〈http://www.ipcc.ch/publications_and_ data/ar4/wg1/en/ch5s5-4-2-3.html $>$ (accessed 14.09.11).

Streets, D., Zhang, Q., Wu, Y., 2009. Projections of global mercury emissions in 2050. Environ. Sci. Technol. 43, 2983-2988.

Sunderland, E.M., Kriens, D., von Stackelberg, K., 2012. Pilot Analysis of Gulf of Mexico State Residents' Methylmercury Exposures from Commercial and
Locally Caught Fish: Final Report Submitted to the Florida Department of Environmental Protection, March 15, 2012.

Sunderland, E.M., Krabbenhoft, D.P., Moreau, J.W., Strode, S.A., Landing, W.M., 2009. Mercury sources, distribution, and bioavailability in the North Pacific Ocean: Insights from data and models. Global Biogeochem. Cycles 23 (GB2), 010, http://dx.doi.org/10.1029/2008GB003425.

Sunderland, E.M., 2007. Mercury exposure from domestic and imported estuarine and marine fish in the U.S. seafood market. Environ. Health Perspect. 115 (2), 235-242.

Sunderland, E.M., Mason, R.P., 2007. Human impacts on open ocean mercury concentrations. Global Biogeochem. Cycles 21, GB4022, http://dx.doi.org/ 10.1029/2006GB002876.

Sunderland, E.M., Gobas, F.A.P.C., Branfireun, B.A., Heyes, A., 2006. Environmental controls on the speciation and distribution of mercury in coastal sediments. Mar. Chem. 102, 111-123.

Tan, S.W., Meiller, J.C., Mahaffey, K.R., 2009. The endocrine effects of mercury in humans and wildlife. Crit. Rev. Toxicol. 39, 228-269.

Texas Department of Health (TDH). Fish Tissue Sampling Data 1970-1997. Austin, Texas.

Thera, J., 2011. Trophic Transfer of $\mathrm{Hg}$ in a Subtropical Coastal Food Web off Southwest Florida. Unpublished Master Thesis. Florida Gulf Coast University, Ft. Myers, Florida.

Tremain, D.M., Adams, D.H. Mercury in groupers and sea basses from the Gulf of Mexico: relationships with age, size, and feeding ecology. Trans. Am. Fish. Soc., http://dx.doi.org/10.1080/00028487.2012.683232, in press.

UNEP, 2011. 〈http://www.unep.org/hazardoussubstances/Hg/Negotiations/tabid/ 3320/Default.aspx $>$ (accessed 07.09.11).

UNEP, 2009. The UNEP Large Marine Ecosystem Report. A perspective on Changing Conditions in LMEs of the World's Regional Seas. UNEP Regional Seas and Studies Report No. 182. 〈http://www.lme.noaa.gov/index.php?option=com content\&view=article\&id=178\&Itemid=62 $>$ (accessed 21.09.11)

US EPA, 2011a. 〈http://www.federalregister.gov/articles/2011/05/03/2011-7237/ national-emission-standards-for-hazardous-air-pollutants-from-coal-and-oilfired-electric-utility $>$ (accessed 07.09.11)

US EPA, 2011b. 〈http://www.epa.gov/gmpo/about/facts.html >.

US EPA, 2010. <http://water.epa.gov/type/watersheds/named/msbasin/marb. cfm $\rangle$ (accessed 21.09.11.

US EPA, 2005. U.S. Environmental Protection Agency. Emissions Inventory and Emissions Processing for the Clean Air Mercury Rule (CAMR), March 2005. Accessible from: <http://epa.gov/ttn/atw/utility/emiss_inv_oar-2002-0056-6129. pdf $>$ (accessed 21.09.11)

US EPA, 2003. Mercury in Marine Life Database. Prepared for the U.S. Environmental Protection Agency, Office of Wetlands, Oceans and Watersheds, Oceans and Coastal Protection Division. April 30, 2003.

US EPA, 2002. Estimated Per-capita Fish Consumption in the United States, EPA821-C-02-003. Washington, D.C.: U.S. Environmental Protection Agency.

US EPA, 2001. Water Quality Criterion for the Protection of Human Health: Methylmercury. Office of Science and Technology, Office of Water. EPA-823R-01-001. January 2001. 〈http://water.epa.gov/scitech/swguidance/stan dards/criteria/aqlife/pollutants/methylmercury/upload/2009_01_15_criteria methylmercury_mercury-criterion.pdf $>$ (accessed 21.09.11)

Vidal, L., Pauly, D., 2004. Integration of subsystems models as a tool towards describing feeding interactions and fisheries impacts in a large marine ecosystem, the Gulf of Mexico. Ocean Coastal Manage. 47, 709-725.

Vijayaraghavan, K., Karamchandani, P., Seigneur, C., Balmori, R., Chen, S.-Y., 2008. Plume-in-grid modeling of atmospheric mercury. J. Geophys. Res. 113, D24305, http://dx.doi.org/10.1029/2008JD010580.

Vijayaraghavan, K., Seigneur, C., Karamchandani, P., Chen, S.-Y., 2007. Development and application of a multi-pollutant model for atmospheric mercury deposition. J. Climate Appl. Meteorol. 46, 1341e1353.

Warner, K., 2007. Mercury Levels in Hair of Coastal Alabama Anglers and Residents. Oceana, Washington DC. 〈http://na.oceana.org/sites/default/files/ o/fileadmin/oceana/uploads/mercury/Rodeo_Hair_Report_Final.pdf $\rangle$ (accessed 21.09.11)

Warner, K., Savitz, J., 2006. What's on the Hook: Hg Levels and Fish Consumption at a Gulf of Mexico Fishing Rodeo. Oceana, Washington D. C. (p. 31)

Wells, R.J.D., Chumchal, M.M., Cowan Jr., J.H., 2008. Effect of trawling and habitat on $\mathrm{Hg}$ concentration in juvenile red snapper from the northern Gulf of Mexico. Trans. Am. Fish. Soc. 137, 1839-1850.

Wania, F., 1998. The Significance of Long Range Transport of Persistent Organic Pollutants by Migratory Animals. Report 3/98. WECC Wania Environmental Chemists Corp. Toronto, Ontario, Canada. 〈http://www.utsc.utoronto.ca/ $\sim$ wania/reports/WECC3-1998.pdf $\rangle$ (accessed 21.09.11).

Wiener, J.G., Krabbenhoft, D.P., Heinz, G.H., Scheuhammer, A.M., 2003. Ecotoxicology of mercury. In: Hoffman, D.J., Rattner, B.A., Burton Jr., G.A., Cairns Jr., J. (Eds.), Handbook of Ecotoxicology, 2nd edition CRC Press, Boca Raton, Florida, USA, pp. 407-461. (Chapter 16).

Yeager, K.M., Santschi, P.H., Rowe, G.T., 2004. Sediment accumulation and radionuclide inventories $\left({ }^{239,240} \mathrm{Pu},{ }^{210} \mathrm{~Pb}\right.$ and $\left.{ }^{234} \mathrm{Th}\right)$ in the northern Gulf of Mexico, as influenced by organic matter and macrofaunal density. Mar. Chem. 91, $1-14$

Zhang, X., Naidu, A.S., Kelley, J.J., Jewett, S.C., Dasher, D., Duffy, L.K., 2001. Baseline concentrations of $\mathrm{THg}$ and $\mathrm{MeHg}$ in salmon returning via the Bering Sea (1999-2000). Mar. Pollut. Bull. 42, 993-997. 